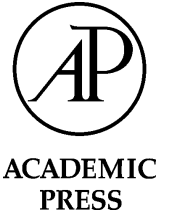

Available online at www.sciencedirect.com

\title{
Reactivity of Fe-binuclear complexes in over-exchanged Fe/ZSM5, studied by in situ XAFS spectroscopy Part 1: Heat treatment in $\mathrm{He}$ and $\mathrm{O}_{2}$
}

\author{
A.A. Battiston, J.H. Bitter, W.M. Heijboer, F.M.F. de Groot, D.C. Koningsberger* \\ Department of Inorganic Chemistry and Catalysis, Debye Institute, Utrecht University, Sorbonnelaan 16, 3584 CA Utrecht, The Netherlands
}

Received 26 September 2002; revised 4 December 2002; accepted 4 December 2002

\begin{abstract}
The structure of the iron species in mildly calcined over-exchanged Fe/ZSM5, prepared by CVD of $\mathrm{FeCl}_{3}$, was studied during heat treatments in $\mathrm{He}$ or $\mathrm{O}_{2} / \mathrm{He}$ (50:50) by coupling in situ Fe K edge HR-XANES and EXAFS. The majority of iron appears to be present as Fe-binuclear complexes. EXAFS shows that the closest Fe-O shell in the complexes can be described with a $[\mathrm{HO}-\mathrm{Fe}-\mathrm{O}-\mathrm{Fe}-\mathrm{OH}]^{2+}$ core. Heating to a moderate temperature (up to $\sim 150^{\circ} \mathrm{C}$ ) results in the desorption of water from the Fe-coordination sphere, in He as well as in a $\mathrm{O}_{2} / \mathrm{He}$ (50:50) mixture. The composition of the gas phase strongly influences the changes occurring to the binuclear complexes in the $150-350{ }^{\circ} \mathrm{C}$ temperature range. Above $250{ }^{\circ} \mathrm{C}$ in He a significant fraction of iron undergoes autoreduction. This is accompanied by the removal of approximately one oxygen atom from the closest $\mathrm{Fe}-\mathrm{O}$ shell, ascribable to the $\mathrm{Fe}-\mathrm{O}-\mathrm{Fe}$ bridging oxygen atom. The presence of oxygen in the gas phase $\left(\mathrm{PO}_{2}=0.5\right.$ bar), on the contrary, suppresses the auto-reduction capability of the binuclear complexes by inhibiting the removal of the $\mathrm{Fe}-\mathrm{O}-\mathrm{Fe}$ bridging oxygen.

(c) 2003 Elsevier Science (USA). All rights reserved.
\end{abstract}

Keywords: Fe/ZSM5; Binuclear; Iron; Red-ox properties; Auto-reduction; Reactivity; Helium; Oxygen

\section{Introduction}

Iron-exchanged ZSM5 has recently attracted considerable attention due to its ability to catalyze diverse selective oxidation reactions. Its activity has been demonstrated for the selective oxidation of benzene to phenol using $\mathrm{N}_{2} \mathrm{O}$ [1-5], the catalytic decomposition of $\mathrm{N}_{2} \mathrm{O}$ [6-9], and for the selective catalytic reduction of nitrogen oxides using hydrocarbons (HC-SCR) [10-12].

While the catalytic properties of iron-exchanged ZSM5 are well established, a debate is open in the literature on the nature and the reactivity of the Fe-active phase. The discussion is complicated by the fact that diverse synthesis techniques are used, resulting in different Fe/ZSM5 materials. These differences concern (i) the way by which iron is loaded (synthesis or post-synthesis methods); (ii) the chemical composition of the starting ZSM5 support ( $\mathrm{Si} / \mathrm{Al}$ ratio);

\footnotetext{
* Corresponding author.

E-mail address: d.c.koningsberger@chem.uu.nl

(D.C. Koningsberger)
}

(iii) the amount of iron loaded; (iv) the activation treatment applied to the obtained Fe/ZSM5 (calcination, activation in vacuo or steaming).

Fe-framework substituted ZSM5, activated by calcination in vacuo or by steaming at high temperature, has shown remarkable activity towards the selective oxidation of benzene to phenol by $\mathrm{N}_{2} \mathrm{O}$ and towards the decomposition of $\mathrm{N}_{2} \mathrm{O}$ [1-9]. Studies by Ribera et al. [5] and Ramírez et al. [13], performed on Fe-framework substituted ZSM5, activated by steaming $(\sim 0.6 \mathrm{Fe} w t \%)$, have shown that during the activation treatment different $\mathrm{Fe}$ species are formed. These species vary from isolated extra framework $\mathrm{Fe}$ oxo-ions and oligonuclear oxo-iron complexes located in the zeolite channels to larger highly dispersed iron-oxide nanoparticles on the external surface of the zeolite. Experiments with 1,3,5trimethylbenzene, too large to fit inside the zeolite pores, have demonstrated that the latter are not involved in the oxidation of benzene to phenol [5]. This observation supports the idea that only highly dispersed Fe species located within the zeolite channels are responsible for the peculiar selective oxidation properties of Fe/ZSM5. Panov and coworkers have ascribed the catalytic activity of this material to the 
presence of extra-framework binuclear iron species, located in the zeolite micropores and formed by extraction of iron from the zeolite matrix during the activation treatment. By reaction with $\mathrm{N}_{2} \mathrm{O}$ these iron centers are believed to be capable of generating a specially reactive oxygen [1-4,14-16]. This oxygen (called $\alpha$-oxygen by the authors) is believed to be responsible for the oxidation of benzene to phenol already at room temperature.

Binuclear Fe oxo-hydroxo species located at the Brønsted site positions of the framework have been proposed to be the active phase also in Fe/ZSM5 prepared by the chemical vapor deposition (CVD) of anhydrous $\mathrm{FeCl}_{3}[7,10,11,17]$. Together with aqueous ion exchange [18] and solid-state ion exchange [19-24], CVD of $\mathrm{FeCl}_{3}$ belongs to the socalled post-synthesis loading techniques. With the CVD technique $\mathrm{Fe}$ is exchanged from the gas phase at around $330^{\circ} \mathrm{C}$ for the $\mathrm{H}^{+}$Brønsted sites of an acidic Al-ZSM5 support. Final steps in the synthesis are a washing procedure, followed by drying in air and calcination in oxygen $[10,25]$. The as-obtained material presents major differences when compared to the activated Fe-framework substituted ZSM5, mentioned earlier. First, a significantly higher iron loading can be achieved ( $\sim 5 \mathrm{Fe}$ wt $\%$, depending on the Si/Al ratio). Secondly, no significant damage occurs to the zeolite framework during the activation (calcination) [25]. This indicates that the formation of active $\mathrm{Fe}$ species does not require extraction of aluminum from the zeolite framework.

The identification of the active phase with binuclear $\mathrm{Fe}$ oxo-hydroxo complexes in $\mathrm{Fe} / \mathrm{ZSM} 5$ by $\mathrm{FeCl}_{3} \mathrm{CVD}$ is based on results obtained by $\mathrm{H}_{2}$ and $\mathrm{CO}$ TPR, FTIR, EPR, and isotopic exchange with ${ }^{18} \mathrm{O}_{2}[7,10,11,17,26]$. The binuclear $\mathrm{Fe}$ complexes, with the proposed core structure $[\mathrm{HO}-\mathrm{Fe}-\mathrm{O}-\mathrm{Fe}-\mathrm{OH}]^{2+}$, are believed to be responsible for the decomposition of $\mathrm{N}_{2} \mathrm{O}$ [7] and for the selective reduction of $\mathrm{NO}$ by hydrocarbons in the presence of excess oxygen $[10,11,26]$.

EXAFS studies performed by Marturano et al. [27,28] and by our group $[25,29]$ have confirmed that, indeed, Febinuclear complexes are largely present in Fe/ZSM5 obtained by CVD. The structure of these binuclear complexes, after washing, resembles that of the closest Fe-binuclear building unit in $\alpha$-goethite $[25,28]$. In this unit two octahedrally coordinated iron atoms are symmetrically connected via two hydroxyl groups [30,31].

A major problem in determining a structure activity relation for the active phase in Fe/ZSM5 is that for activated Feframework substituted ZSM5, as well as for Fe/ZSM5 prepared by $\mathrm{FeCl}_{3} \mathrm{CVD}, \mathrm{Fe}$ species (spectators) different from binuclear complexes are present $[7,17,25,26]$. In particular, Fe-binuclear complexes can undergo agglomeration during calcination [25], finally resulting in the formation of catalytically inactive $[3,10,24]$ goethite and hematite crystals on the external surface of the zeolite. However, as demonstrated in a previous study by our group [25], agglomeration of iron in Fe/ZSM5 obtained by CVD can be controlled by adequately tuning the conditions applied during calcination. Agglomer- ation of Fe species can be significantly suppressed by applying a mild calcination procedure, obtained by coupling a moderate temperature ramp with a high gas flow rate. The resulting mildly calcined Fe/ZSM5 is, therefore, the best suited material for establishing a structure-activity relation for Fe/ZSM5 synthesized by CVD.

The objective of this work is to study the reactivity of the $\mathrm{Fe}$ species present in $\mathrm{Fe} / \mathrm{ZSM} 5$ obtained by CVD of $\mathrm{FeCl}_{3}$. The reactivity of oxygen is of particular interest since it represents the key step for the decomposition of $\mathrm{N}_{2} \mathrm{O}$ [7], as well as for the HC-SCR of NO [10,11,17,26]. The oxidation state of iron and its local environment in a mildly calcined Fe/ZSM5 sample have been monitored during heating treatments in $\mathrm{He}$ and $\mathrm{O}_{2}$, by combining the results of in situ EXAFS and high-resolution (HR)-XANES. The HRXANES of the Fe K edge, especially the pre-edge feature (related to $1 \mathrm{~s} \rightarrow 3 \mathrm{~d}$ metal electronic transitions [32-34]), provides detailed information on both the oxidation state of iron and the coordination geometry [35]. This information can be used as input for the analysis of the EXAFS data. Furthermore, both HR-XANES and EXAFS benefit from the advantage of being applicable in situ, i.e., at reaction temperature and in the presence of reactants. Their combination is, therefore, a powerful tool for tracking structural changes occurring on iron during gas treatments and catalytic reactions. From the results obtained in this study a model will be proposed for the reactivity of the Fe species present in Fe/ZSM5 during heating treatments in helium and oxygen. In a subsequent paper a structure activity relation will be presented for the selective reduction of NO by hydrocarbons in the presence of excess oxygen $[10,11,26]$.

\section{Experimental}

\subsection{Preparation of the sample}

Over-exchanged $\mathrm{Fe} / \mathrm{ZSM} 5$ was prepared following the $\mathrm{FeCl}_{3} \mathrm{CVD}$ method proposed by Chen et al. [10] and extensively described in our previous work [25]. Particular attention was paid to calcination. The procedure applied (mild calcination) was identical to the procedure proposed in our previous work [25]. The sample was heated under a He flow of $800 \mathrm{ml} / \mathrm{min}$ with a moderate temperature ramp $\left(0.5^{\circ} \mathrm{C} / \mathrm{min}\right)$ to $200^{\circ} \mathrm{C}$. At this temperature, $200 \mathrm{ml} / \mathrm{min}$ of $\mathrm{O}_{2}$ were added to the $\mathrm{He}$ flow while, under the same temperature ramp, heating was continued to $550^{\circ} \mathrm{C}$. After $3 \mathrm{~h}$ at $550^{\circ} \mathrm{C}$, the temperature was decreased to $30^{\circ} \mathrm{C}$. The resulting sample, stored in air, will be referred to as $\mathrm{Fe} /$ ZSM5.

\subsection{ICP, $N_{2}$ physisorption, $X R D$}

The elemental composition of the starting H/ZSM5 support and of Fe/ZSM5 was determined by using inductively 
coupled plasma emission spectroscopy. $0.10 \mathrm{~g}$ of the samples were mixed in a platinum cup together with $0.40 \mathrm{~g}$ of Li-tetraborate and $0.20 \mathrm{~g}$ of Li-metaborate and heated to $925^{\circ} \mathrm{C}$. This temperature was maintained for $1 \mathrm{~h}$. After cooling, the resulting soluble borate was dissolved in $330 \mathrm{ml} \mathrm{HCl}$ $(1.0 \mathrm{M})$, diluted to $1000 \mathrm{ml}$ with doubly deionized water, and analyzed.

The micropore volume of the acidic support and of Fe/ZSM5 (after washing and after calcination) was determined by $\mathrm{N}_{2}$ physisorption, using a Micromeritics ASAP 2010, as described in [25]. $\mathrm{N}_{2}$ physisorption data obtained on sample Fe/ZSM5 were corrected for the additional metal loading $(\sim 4.4 \mathrm{wt} \%)$ for comparison with the H/ZSM5 support.

XRD diffractograms obtained from the acidic support and from the Fe/ZSM5 sample (after washing and after calcination) were compared to visualize possible lattice damage or formation of additional Fe-rich crystalline phases. $\mathrm{X}$-ray diffraction patterns were recorded using a Nonius PDS 120 powder diffractometer. The radiation used was Co- $\mathrm{K}_{\alpha_{1}}$ $(\lambda=1.78897 \AA)$. Diffractograms were recorded for $24 \mathrm{~h}$ and averaged in order to optimize the signal-to-noise ratio.

\subsection{Fe K-edge HR-XANES}

High-resolution X-ray Absorption Near Edge Spectroscopy was applied in order to study the oxidation state and the coordination geometry of $\mathrm{Fe}$ in $\mathrm{Fe} / \mathrm{ZSM} 5$. This information was obtained by analyzing the features (centroid position and integrated intensity) of the Fe K pre-edge, located 15$20 \mathrm{eV}$ before the main Fe K-edge crest. The HR-XANES measurements at the $\mathrm{Fe} \mathrm{K}$ edge were carried out at the undulator beamline ID16 at the ESRF (Grenoble, France). Details about the experimental setup are given in [36] and in our previous paper [25].

\subsubsection{HR-XANES data collection}

Fe/ZSM5 was pressed into self-supporting wafers and placed in an in situ fluorescence cell [37] at $45^{\circ}$ with respect to the beam. Spectra were recorded at 1 bar during heating treatments from 30 to $350^{\circ} \mathrm{C}$ (heating ramp of $\left.3^{\circ} \mathrm{C} / \mathrm{min}\right)$. The heating treatments were performed under different atmospheres, i.e., flowing $\mathrm{He}(100 \mathrm{ml} / \mathrm{min})$ or a $50: 50 \mathrm{He} / \mathrm{O}_{2}$ flowing mixture (total flow $=100 \mathrm{ml} / \mathrm{min}$ ). The sample heated up in $\mathrm{He}$, after $30 \mathrm{~min}$ stabilization (under flowing $\mathrm{He}$ ) at $350^{\circ} \mathrm{C}$, was flushed with a $50: 50$ $\mathrm{He} / \mathrm{H}_{2}$ mixture (total flow $=100 \mathrm{ml} / \mathrm{min}, T=350^{\circ} \mathrm{C}$ ) and measured after $15 \mathrm{~min}$ under the same conditions. Hematite was measured under static $\mathrm{He}$ at $30^{\circ} \mathrm{C}$ as internal reference.

\subsubsection{HR-XANES data processing}

The fluorescence Fe K XANES spectra were normalized by the average absorption intensity, calculated in the 7200$7300 \mathrm{eV}$ region. To isolate the pre-edge feature, the contribution to the pre-edge of the main Fe K edge was subtracted from the normalized XANES spectra. This contribution was calculated using a cubic spline function, obtained by interpolating the data several $\mathrm{eV}$ before and after the pre-edge [35].

The recorded HR-XANES spectra revealed the presence of fluorescence saturation effects. This was revealed by comparing the maximum intensity of the isolated pre-edges of the normalized HR-XANES spectra measured in fluorescence with those measured (on the same samples) in transmission mode at beamline X1.1 at Hasylab (vide infra). Nevertheless, numerical comparison showed that, as far as the pre-edge is concerned, it was possible to correct for the saturation effects by dividing the maximum intensity of the isolated fluorescence pre-edges by that of the corresponding pre-edges measured in transmission. This procedure was performed independently on the hematite reference and on sample Fe/ZSM5, measured at $30^{\circ} \mathrm{C}$ in $\mathrm{He}$. The correction factor obtained for $\mathrm{Fe} / \mathrm{ZSM} 5$ measured at $30^{\circ} \mathrm{C}$ in $\mathrm{He}$ was used to normalize also the pre-edge data of $\mathrm{Fe} / \mathrm{ZSM} 5$ measured at higher temperatures and in different environments $\left(\mathrm{He} / \mathrm{O}_{2}, \mathrm{He} / \mathrm{H}_{2}\right)$. The rightness of the correction applied was further confirmed by using the procedure outlined in [38], based on intensity dependent correction of the occurring saturation.

The characteristics of the isolated pre-edges, i.e., centroid position and integrated intensity were calculated using the Grams software. Prior to calculations, the pre-edge of $\alpha$ - $\mathrm{Fe}_{2} \mathrm{O}_{3}$ (not shown here, see [25]) was deconvoluted into pseudo-Voigt components (50\% Gaussian, 50\% Lorentzian peak shapes). The contribution from components centered above $7115.0 \mathrm{eV}$ was ignored [32,35]. The estimated accuracy in the energy determination for the HR-XANES spectra presented in this study is $\pm 0.05 \mathrm{eV}$, while the error in the integrated intensity is $\pm 5 \%$.

\subsection{Fe K-edge XAFS}

Fe K-edge XAFS was applied in order to study the Feoxidation state and the local atomic environment around iron, i.e., number, distances, and chemical nature of $\mathrm{Fe}$ neighbors. The XAFS data were collected at the Wiggler station X1.1 of Hasylab (Hamburg, Germany). The experimental setup is described in [25].

\subsubsection{XAFS data collection}

$\mathrm{Fe} / \mathrm{ZSM} 5$ was pressed to obtain self-supporting wafers, calculated to have an absorbency $(\mu * x)$ of 2.5 , and placed in a controlled atmosphere cell. The cell is similar to that used for the HR-XANES fluorescence measurements and is described in detail elsewhere [37]. The samples were treated in situ under flowing $\mathrm{He}(50 \mathrm{ml} / \mathrm{min})$ or under a $50: 50 \mathrm{O}_{2} / \mathrm{He}$ mixture (total flow of $50 \mathrm{ml} / \mathrm{min}$ ). They were heated under the mentioned flows to 120 or $350^{\circ} \mathrm{C}$, applying a temperature ramp of $5^{\circ} \mathrm{C} / \mathrm{min}$. Spectra were recorded at working temperature (under flowing atmospheres) or, with the cell closed, after being cooled to $77 \mathrm{~K}$. A list of the measurements performed on sample Fe/ZSM5, including informa- 
Table 1

List of XAFS spectra recorded from Fe/ZSM5: pretreatments and measuring conditions

\begin{tabular}{|c|c|c|c|}
\hline $\begin{array}{l}\text { Pretreatments } \\
\text { (flowing atmosphere) }\end{array}$ & $\begin{array}{l}\text { Environ. conditions } \\
\text { during measurement }\end{array}$ & Aver. scans & Measurements code \\
\hline $\mathrm{He}, 15 \mathrm{~min}, 30^{\circ} \mathrm{C}$ & Static He, $77 \mathrm{~K}$ & 3 & $\mathrm{Fe} / \mathrm{ZSM} 5-\mathrm{He} 30^{\circ} \mathrm{C} / \mathrm{LN}$ \\
\hline$\uparrow \mathrm{He}, 30 \mathrm{~min}$ at $120^{\circ} \mathrm{C}$ & Static He, $77 \mathrm{~K}$ & 3 & $\mathrm{Fe} / \mathrm{ZSM} 5-\mathrm{He} 120^{\circ} \mathrm{C} / \mathrm{LN}$ \\
\hline$\uparrow \mathrm{He}, 30 \mathrm{~min}$ at $350^{\circ} \mathrm{C}$ & Flowing $\mathrm{He}, 350^{\circ} \mathrm{C}$ & 1 & $\mathrm{Fe} / \mathrm{ZSM} 5-\mathrm{He} 350^{\circ} \mathrm{C}(1 \mathrm{st}) / 350^{\circ} \mathrm{C}$ \\
\hline$\uparrow \mathrm{He}, 60 \mathrm{~min}$ at $350^{\circ} \mathrm{C}$ & Flowing $\mathrm{He}, 350^{\circ} \mathrm{C}$ & 1 & $\mathrm{Fe} / \mathrm{ZSM} 5-\mathrm{He} 350^{\circ} \mathrm{C}(2 \mathrm{nd}) / 350^{\circ} \mathrm{C}$ \\
\hline$\uparrow \mathrm{He}, 90 \mathrm{~min}$ at $350^{\circ} \mathrm{C}$ & Flowing $\mathrm{He}, 350{ }^{\circ} \mathrm{C}$ & 1 & $\mathrm{Fe} / \mathrm{ZSM} 5-\mathrm{He} 350^{\circ} \mathrm{C}(3 \mathrm{rd}) / 350^{\circ} \mathrm{C}$ \\
\hline$\uparrow \mathrm{He}, 120 \mathrm{~min}$ at $350^{\circ} \mathrm{C}$ & Static He, $77 \mathrm{~K}$ & 3 & $\mathrm{Fe} / \mathrm{ZSM} 5-\mathrm{He} 350^{\circ} \mathrm{C} / \mathrm{LN}$ \\
\hline$\uparrow \mathrm{O}_{2} / \mathrm{He}, 60 \mathrm{~min}$ at $350^{\circ} \mathrm{C}$ & Flowing $\mathrm{O}_{2} / \mathrm{He}, 350^{\circ} \mathrm{C}$ & 3 & $\mathrm{Fe} / \mathrm{ZSM} 5-\mathrm{O}_{2} 350^{\circ} \mathrm{C} / 350^{\circ} \mathrm{C}$ \\
\hline$\uparrow \mathrm{O}_{2} / \mathrm{He}, 120 \mathrm{~min}$ at $350^{\circ} \mathrm{C}$ & Static $\mathrm{O}_{2} / \mathrm{He}, 77 \mathrm{~K}$ & 3 & $\mathrm{Fe} / \mathrm{ZSM} 5-\mathrm{O}_{2} 350^{\circ} \mathrm{C} / \mathrm{LN}$ \\
\hline
\end{tabular}

$\uparrow=$ Heating treatment $\left(5^{\circ} \mathrm{C} / \mathrm{min}\right)$.

tion on pretreatments, measuring conditions, number of averaged scans, and measurements codes, is given in Table 1. XANES spectra of hematite and Fe-titanate were also measured and used, respectively, as internal $\mathrm{Fe}^{\mathrm{III}}$ and $\mathrm{Fe}^{\mathrm{II}}$ references.

\subsubsection{XAFS data processing}

Extraction of the EXAFS data from the measured absorption spectra was performed with the XDAP code developed by Vaarkamp et al. [39]. Three scans were recorded for each measurement and averaged. In the case of significant differences between the three scans, spectra were analyzed separately (see Table 1 , scans Fe/ZSM5-He $350{ }^{\circ} \mathrm{C}$ (1st, 2nd, 3rd) $/ 350^{\circ} \mathrm{C}$ ). The pre-edge was subtracted using a modified Victoreen curve [40]. The background was subtracted employing cubic spline routines with a continuously adjustable smooth parameter $[41,42]$. Normalization was performed by dividing the data by the intensity of the absorption spectrum at $50 \mathrm{eV}$ above the $\mathrm{Fe} \mathrm{K}$ edge.

\subsubsection{EXAFS $\mathrm{Fe}-\mathrm{O}, \mathrm{Fe}-\mathrm{Fe}$ references, data analysis}

The $\mathrm{Fe}-\mathrm{O}$ reference used for the EXAFS data analysis was created from experimental EXAFS data, obtained from ferric acetylacetonate (measured at L.N. temperature). The $\mathrm{Fe}-\mathrm{Fe}$ phase shifts and backscattering amplitudes were calculated using the software FEFF7 [43]. The theoretical $\mathrm{Fe}-\mathrm{Fe}$ reference was calibrated on EXAFS data obtained from hematite at L.N. temperature, by fitting in $R$ space. The complete procedure followed for the creation and the calibration of the EXAFS Fe-O and the Fe-Fe references is reported in [25].

The EXAFS data analysis was performed by applying multiple-shell fitting in $R$ space [41]. The difference file technique was applied to resolve the different contributions in the EXAFS data. The EXAFS fits were checked by applying $k^{1}, k^{2}$, and $k^{3}$ weightings.

The number of independent fit parameters $\left(N_{\text {indp }}\right)$ was determined by equation

$N_{\text {indp }}=\frac{2 \Delta k \Delta R}{\pi}+2$,

as outlined in the Reports on Standard and Criteria in XAFS Spectroscopy [44]. Errors in the numerical values obtained
Table 2

Elemental composition (ICP) and micropore volume $\left(\mathrm{N}_{2}\right.$ physisorption) of $\mathrm{H}$ /ZSM5 (starting support) and of Fe/ZSM5, after washing (Fe/ZSM5-w) and after washing followed by a mild calcination $(\mathrm{Fe} / \mathrm{ZSM} 5-\mathrm{w}+\mathrm{mc})$

\begin{tabular}{lccc}
\hline Samples & $\begin{array}{c}\mathrm{Si} / \mathrm{Al} \\
\text { (atomic ratio) }\end{array}$ & $\begin{array}{c}\mathrm{Fe} / \mathrm{Al} \\
\text { (atomic ratio) }\end{array}$ & $\begin{array}{c}\text { Micropore } \\
\text { volume } \\
\left(\mathrm{cm}^{3} / \mathrm{g}_{\text {support }}\right)\end{array}$ \\
\hline H/ZSM5 & 17.0 & 0.0 & 0.15 \\
Fe/ZSM5-w & 17.4 & 1.0 & 0.12 \\
Fe/ZSM5-w + mc & 17.2 & 1.0 & 0.12 \\
\hline
\end{tabular}

by the EXAFS data analysis are estimated to be $\pm 10 \%$ in the coordination number $(N), \pm 1 \%$ in the distance $(R), \pm 5 \%$ in the Debye-Waller factor $\left(\Delta \sigma^{2}\right)$, and $\pm 10 \%$ in the inner potential correction $\left(\Delta E_{0}\right)[45]$.

\section{Results}

\subsection{ICP, $N_{2}$ physisorption, $X R D$}

Table 2 shows the elemental composition and the micropore volume of the parent H/ZSM5 support and of the $\mathrm{Fe} / \mathrm{ZSM} 5$ sample after washing, and upon mild calcination. The $\mathrm{Si} / \mathrm{Al}$ ratio in the starting support and in the obtained $\mathrm{Fe} / \mathrm{ZSM} 5$ is, within the margin of error, the same. This result shows that no aluminum was leached out during the synthesis [25]. The Fe/Al of 1.0 is a typical result of the $\mathrm{FeCl}_{3} \mathrm{CVD}$ technique, by which a complete exchange of $\mathrm{Fe}^{\mathrm{III}}$ for the Brønsted protons of the support is obtained. It should nevertheless be noted that, as shown in previous works [21,25,27], partial removal of Fe from the Brønsted sites may occur during washing and calcination.

After the loading of iron, a decrease of around $20 \%$ was detected in the micropore volume of the ZSM5 support (Fe/ZSM5-w). No further changes were visible upon mild calcination. This shows that applying a mild calcination procedure does not result in significant removal of iron to the external surface of the zeolite. This observation was confirmed by HR-TEM measurements shown in [25].

X-ray diffractograms (not shown), collected after the subsequent steps of the Fe/ZSM5 synthesis, did not show any change in the diffraction peaks. This indicates that no 
detectable damage to the ZSM5 framework is observed, nor the presence of additional Fe oxidic or oxo-hydroxidic crystalline phases.

\subsection{Fe K-edge HR-XANES}

Fig. 1a shows the normalized background subtracted high-resolution pre-edges isolated from the HR-XANES spectra of Fe/ZSM5, measured during the heating treatment in helium. By increasing the temperature from 30 to $130^{\circ} \mathrm{C}$ a clear enhancement was detected in the pre-edge intensity, while no significant shift was visible in the pre-edge posi-
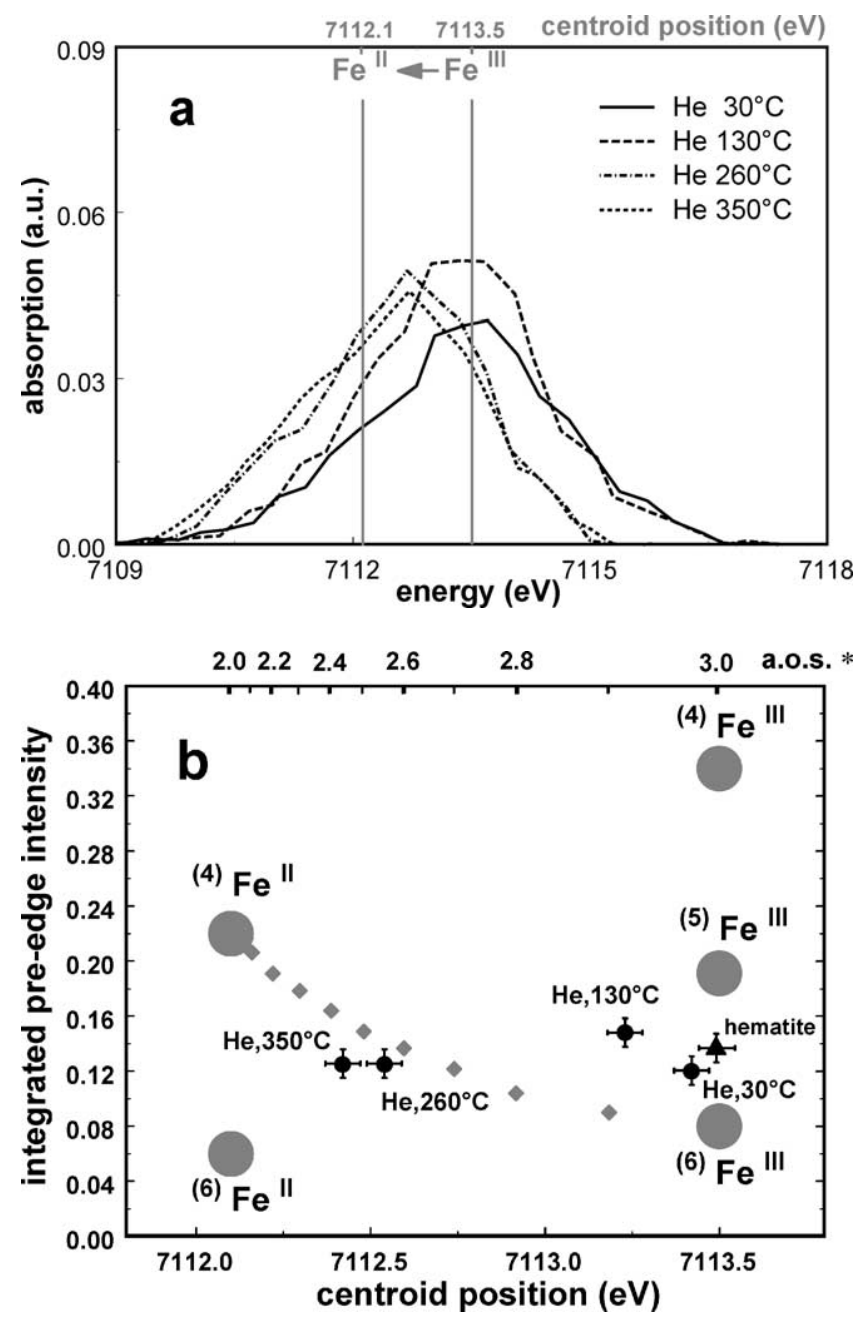

Fig. 1. (a) Normalized high-resolution background substracted pre-edge spectra of $\mathrm{Fe} / \mathrm{ZSM} 5$, measured during heat treatment in $\mathrm{He}$ (1 bar, $100 \mathrm{ml} / \mathrm{min}$, heating $\mathrm{ramp} 3{ }^{\circ} \mathrm{C} / \mathrm{min}$ ); (b) Summary of pre-edge characteristics (centroid position and integrated intensity) of Fe/ZSM5 (-), measured during heating treatment in He. Pre-edge characteristics of ${ }^{(6)} \mathrm{Fe}^{\mathrm{III}}$, ${ }^{(5)} \mathrm{Fe}^{\mathrm{III}},{ }^{(4)} \mathrm{Fe}^{\mathrm{III}},{ }^{(6)} \mathrm{Fe}^{\mathrm{II}},{ }^{(4)} \mathrm{Fe}^{\mathrm{II}}(\mathrm{O})$ and ${ }^{(6)} \mathrm{Fe}^{\mathrm{III}} /{ }^{(4)} \mathrm{Fe}^{\mathrm{II}}$ binary mixtures $(\diamond)$, obtained from the literature [35], are reported for comparison, together with the experimental pre-edge features of hematite $(\boldsymbol{\Lambda})$. The diagram does not consider five-coordinated $\mathrm{Fe}^{\mathrm{II}} / \mathrm{Fe}^{\mathrm{III}}$ combinations, as well as ternary or more complex mixtures. $*$ The average oxidation number of the ${ }^{(6)} \mathrm{Fe}^{\mathrm{III}} /{ }^{(4)} \mathrm{Fe}^{\mathrm{II}}$ binary mixtures is reported in the upper $x$-axis against the corresponding energy of the centroid positions (lower $x$-axis). tion. An additional increase of the temperature to $260^{\circ} \mathrm{C}$ caused a clear shift of the pre-edge toward lower energy, accompanied by only a slight decrease in the maximum intensity and in the area (integrated intensity) of the pre-edge. Reaching the final temperature of $350^{\circ} \mathrm{C}$ resulted in an additional minor shift toward lower energy, while no further changes were measured in the pre-edge area.

The characteristics (integrated intensity vs centroid position) of the pre-edges of Fe/ZSM5, measured during the heating treatment in helium, are plotted in Fig. 1b with small black dots. This figure also gives the pre-edge features of well-defined $\mathrm{Fe}$-crystalline materials, with known Fe-oxidation state and coordination geometry. Here II and III give the $\mathrm{Fe}$ oxidation states, while the number between brackets in the superscript represents the number of oxygen neighboring atoms. Single-phase Fe compounds are indicated with large gray dots, while binary mixtures of ${ }^{(6)} \mathrm{Fe}^{\mathrm{III}} /{ }^{(4)} \mathrm{Fe}^{\mathrm{II}}$ are plotted with small gray lozenges. As a comparison, the results obtained for hematite measured in $\mathrm{He}$ at $30^{\circ} \mathrm{C}$ are also shown, depicted with a triangle.

The pre-edge features of the $\mathrm{Fe}$ references have been obtained from the work of Wilke et al. [35]. In their work the authors have shown that, irrespectively of the coordination geometry, the centroid position of $\mathrm{Fe}^{\mathrm{II}}$ and $\mathrm{Fe}^{\mathrm{III}}$ are separated by $1.4 \pm 0.1 \mathrm{eV}$ and are positioned at 7112.1 and $7113.5 \mathrm{eV}$, respectively. At a given oxidation state, the lowest pre-edge integrated intensity corresponds to the most centrosymmetric coordination of iron $\left({ }^{(6)} \mathrm{Fe}\right)$. A decrease in symmetry, as well as in the number of coordinated neighbors $\left({ }^{(6)} \mathrm{Fe} \rightarrow{ }^{(4)} \mathrm{Fe}\right.$ ), results in an increase of the preedge integrated intensity. The variation in pre-edge intensity is larger for $\mathrm{Fe}^{\mathrm{III}}$ compounds.

The results of Wilke et al. obtained for binary mixtures of ${ }^{(6)} \mathrm{Fe}^{\mathrm{III}} /{ }^{(4)} \mathrm{Fe}^{\mathrm{II}}$ are important to understand the changes in the coordination geometry of $\mathrm{Fe}$ in $\mathrm{Fe} / \mathrm{ZSM} 5$, as a function of the heat treatment in $\mathrm{He}$. The authors have systematically varied the ${ }^{(6)} \mathrm{Fe}^{\mathrm{III}} /{ }^{(4)} \mathrm{Fe}^{\mathrm{II}}$ molar ratio of a binary mixture. In their XANES study they determined the centroid position and the integrated intensity of the pre-edge feature of the different mixtures. The average oxidation state of the ${ }^{(6)} \mathrm{Fe}^{\mathrm{III}} /{ }^{(4)} \mathrm{Fe}^{\mathrm{II}}$ binary mixtures is given here in the upper $x$-axis as a function of the corresponding energy of the centroid positions (lower $x$-axis). It should be noted that the average red-ox state and integrated intensity of iron varies non linearly with the pre-edge position. This phenomenon is caused by the different contributions to the pre-edge intensity from tetrahedrally and octahedrally coordinated $\mathrm{Fe}$ atoms.

By comparing the data obtained for Fe/ZSM-5 with those of the references, it can be concluded that iron in $\mathrm{Fe} / \mathrm{ZSM} 5$ measured in $\mathrm{He}$ at $30^{\circ} \mathrm{C}$ is present as slightly distorted octahedrally coordinated $\mathrm{Fe}^{\mathrm{III}}$. Its oxidation state and coordination geometry appear, indeed, to be very similar to that of the hematite reference. By heating Fe/ZSM5 in $\mathrm{He}$ to $130^{\circ} \mathrm{C}$ an increase is visible in the pre-edge integrated intensity, while only a slight shift $(-0.2 \mathrm{eV})$ 
of the centroid position is observed. The main effect of moderate heating in $\mathrm{He}$ is a decrease in symmetry or/and in the number of neighbors coordinated to iron, without a significant reduction in the average Fe-oxidation state. A plausible interpretation for these results appears to be the incipient removal of water molecules from the coordination of iron.

An additional increase of the temperature to $260^{\circ} \mathrm{C}$ caused a clear shift of the pre-edge $(-0.7 \mathrm{eV})$, together with only a slight decrease of its integrated intensity. As can be seen in Fig. 1b, the features of the pre-edge at $260^{\circ} \mathrm{C}$ in $\mathrm{He}$ appear to be similar to that of a $50: 50{ }^{(6)} \mathrm{Fe}^{\mathrm{III}} /{ }^{(4)} \mathrm{Fe}^{\mathrm{II}}$ mixture. Although only qualitative conclusions can be deduced, the results clearly show the onset, above $130^{\circ} \mathrm{C}$, of reduction phenomena involving a considerable fraction of iron. The reduction is accompanied by an additional decrease in the average Fe-coordination number. This can be ascribed to a further desorption of water and, coherently with the chemical reduction of iron, to removal of oxygen. The features of the pre-edge appear to be only slightly affected (additional slight reduction) by an increase of the temperature from 260 to $350^{\circ} \mathrm{C}$.

Fig. 2a shows the normalized high-resolution background subtracted pre-edges of $\mathrm{Fe} / \mathrm{ZSM} 5$, measured during heating in oxygen from 30 to $350^{\circ} \mathrm{C}\left(\mathrm{O}_{2} / \mathrm{He}=50: 50\right)$. The preedge measured in $\mathrm{He}$ at $30^{\circ} \mathrm{C}$ is also given for comparison. Heating $\mathrm{Fe} / \mathrm{ZSM} 5$ in oxygen to $160^{\circ} \mathrm{C}$ resulted in a strong increase in the pre-edge intensity. This increase is almost identical to that measured under $\mathrm{He}$ at $130^{\circ} \mathrm{C}$ (see Fig. 1a). Increasing the temperature further to $350^{\circ} \mathrm{C}$ did not cause any major change with respect to both the pre-edge position and its intensity. These results are visualized in Fig. $2 \mathrm{~b}$. Heating in the presence of oxygen caused a decrease in the centrosymmetry of $\mathrm{Fe}$ but did not result in chemical reduction of $\mathrm{Fe}$. This can be ascribed to the removal of coordinated water molecules. As can be seen, the average $\mathrm{Fe}$ pre-edge features measured on Fe/ZSM5 in oxygen at $350{ }^{\circ} \mathrm{C}$ resembles those of five-fold coordinated $\mathrm{Fe} \mathrm{III}^{\mathrm{II}}$.

Completely different results were obtained on the Fe preedge measured in $\mathrm{H}_{2}$ at $350^{\circ} \mathrm{C}$, after preheating in $\mathrm{He}$ at the same temperature (see Fig. 2a). The pre-edge is clearly shifted to lower energy $(-1.3 \mathrm{eV}$, when compared to the reference sample) and its integrated intensity appears to be increased. The pre-edge characteristics in $\mathrm{H}_{2}$ at $350{ }^{\circ} \mathrm{C}$ are very close to that of tetrahedrally coordinated $\mathrm{Fe}^{\mathrm{II}}$, as depicted in Fig. 2b. Thus, the reduction process affected almost all of the Fe atoms in sample Fe/ZSM5.

\subsection{Fe K-edge XAFS}

\subsubsection{Heat treatment in $\mathrm{He}$}

The effects of the heating treatment in He on the oxidation state of iron are visualized in Fig. 3a. The picture shows the XANES spectra of Fe/ZSM5, measured at liquid nitrogen temperature after treatment in $\mathrm{He}$ at $30^{\circ} \mathrm{C}, 120^{\circ} \mathrm{C}$, and at $350^{\circ} \mathrm{C}$ (after $120 \mathrm{~min}$ stabilization). The XANES spectra
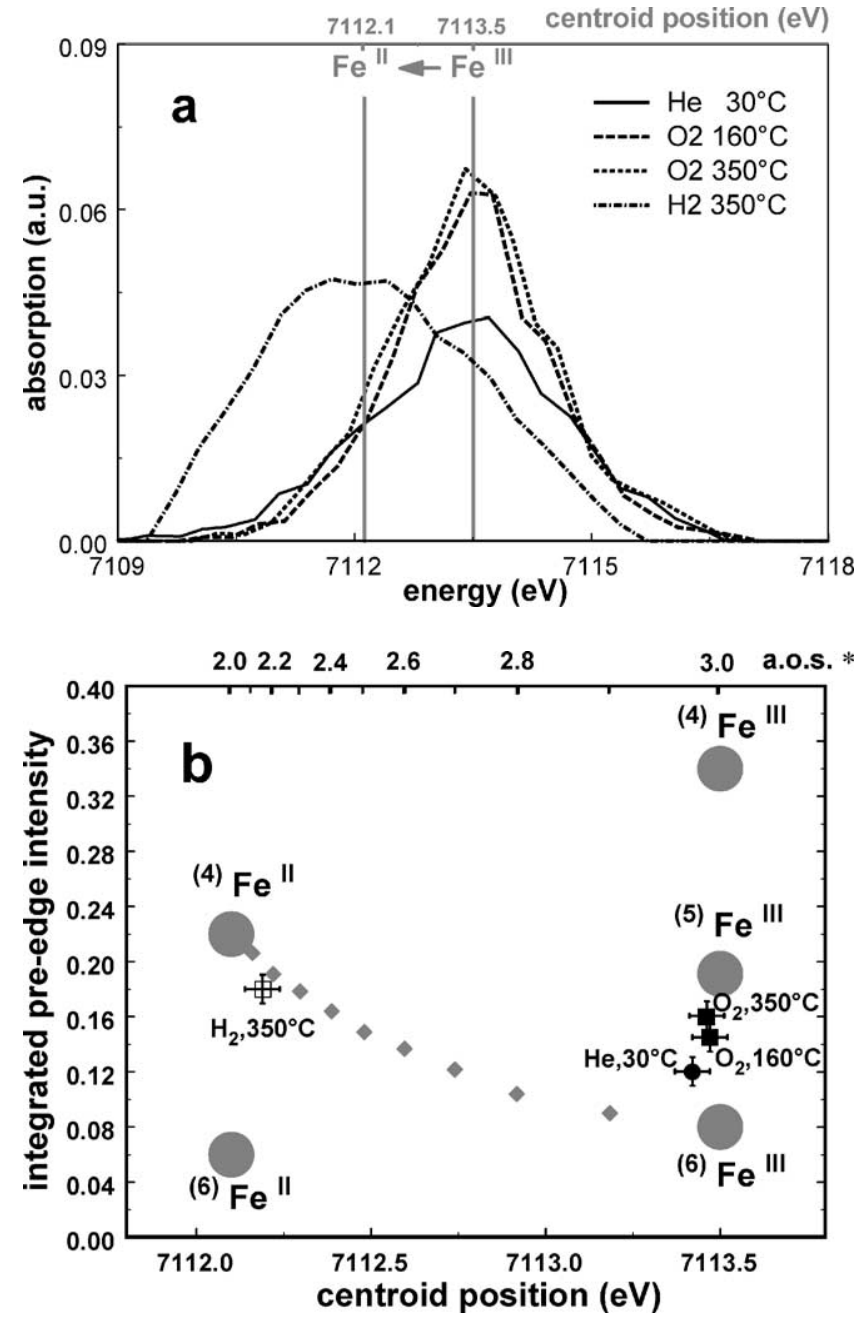

Fig. 2. (a) Normalized high-resolution background substracted pre-edge spectra of $\mathrm{Fe} / \mathrm{ZSM} 5$, measured during heat treatment (heating ramp of $3{ }^{\circ} \mathrm{C} / \mathrm{min}$ ) in oxygen $\left(1 \mathrm{bar}, 100 \mathrm{ml} / \mathrm{min}, \mathrm{O}_{2} / \mathrm{He}=50: 50\right)$, and measured in hydrogen $\left(1 \mathrm{bar}, 100 \mathrm{ml} / \mathrm{min}, \mathrm{H}_{2} / \mathrm{He}=50: 50\right)$ at $350{ }^{\circ} \mathrm{C}$, after heat treatment in $\mathrm{He}$ to $350{ }^{\circ} \mathrm{C}\left(1 \mathrm{bar}, 100 \mathrm{ml} / \mathrm{min}\right.$, heating ramp of $\left.3^{\circ} \mathrm{C} / \mathrm{min}\right)$. (b) Summary of pre-edge characteristics of Fe/ZSM5 measured at $30^{\circ} \mathrm{C}$ in helium (O), during heat treatment in oxygen $(\mathbf{\square})$, and measured in hydrogen at $350{ }^{\circ} \mathrm{C}(\square)$ after heat treatment in $\mathrm{He}$ to $350^{\circ} \mathrm{C}$. For details on $\mathrm{Fe}$ references [35] see the caption to Fig. 1b.

of hematite and $\mathrm{Fe}$-titanate are also reported, respectively, as internal $\mathrm{Fe}^{\mathrm{III}}$ and $\mathrm{Fe}^{\mathrm{II}}$ references. As can be seen from the picture, the $\mathrm{Fe} \mathrm{K}$-edge position of $\mathrm{Fe} / \mathrm{ZSM} 5$ at $30^{\circ} \mathrm{C}$ corresponds to that of hematite $\left(\mathrm{Fe}^{\mathrm{III}}\right)$. Consistently with what observed by HR-XANES, heating to $120^{\circ} \mathrm{C}$ does not result in reduction of iron. A real reduction is observed only upon heating in $\mathrm{He}$ to $350^{\circ} \mathrm{C}$.

Fig. $3 \mathrm{~b}$ shows the experimental EXAFS data (measured in $\mathrm{He}$ at $77 \mathrm{~K}$ ) of $\mathrm{Fe} / \mathrm{ZSM} 5-\mathrm{He} 30^{\circ} \mathrm{C} / \mathrm{LN}$ (solid line), $\mathrm{Fe} / \mathrm{ZSM} 5-\mathrm{He} 120^{\circ} \mathrm{C} / \mathrm{LN}$ (dotted line), and Fe/ZSM5-He $350^{\circ} \mathrm{C} / \mathrm{LN}$ (dashed line). Sample Fe/ZSM5-He $350^{\circ} \mathrm{C} / \mathrm{LN}$ was measured after $120 \mathrm{~min}$ stabilization in $\mathrm{He}$ at $350^{\circ} \mathrm{C}$. Fig. 3b shows that both the EXAFS amplitude and the nodes in $k$ space are affected by the treatment in $\mathrm{He}$, thus heating in He resulted in significant changes affecting the 

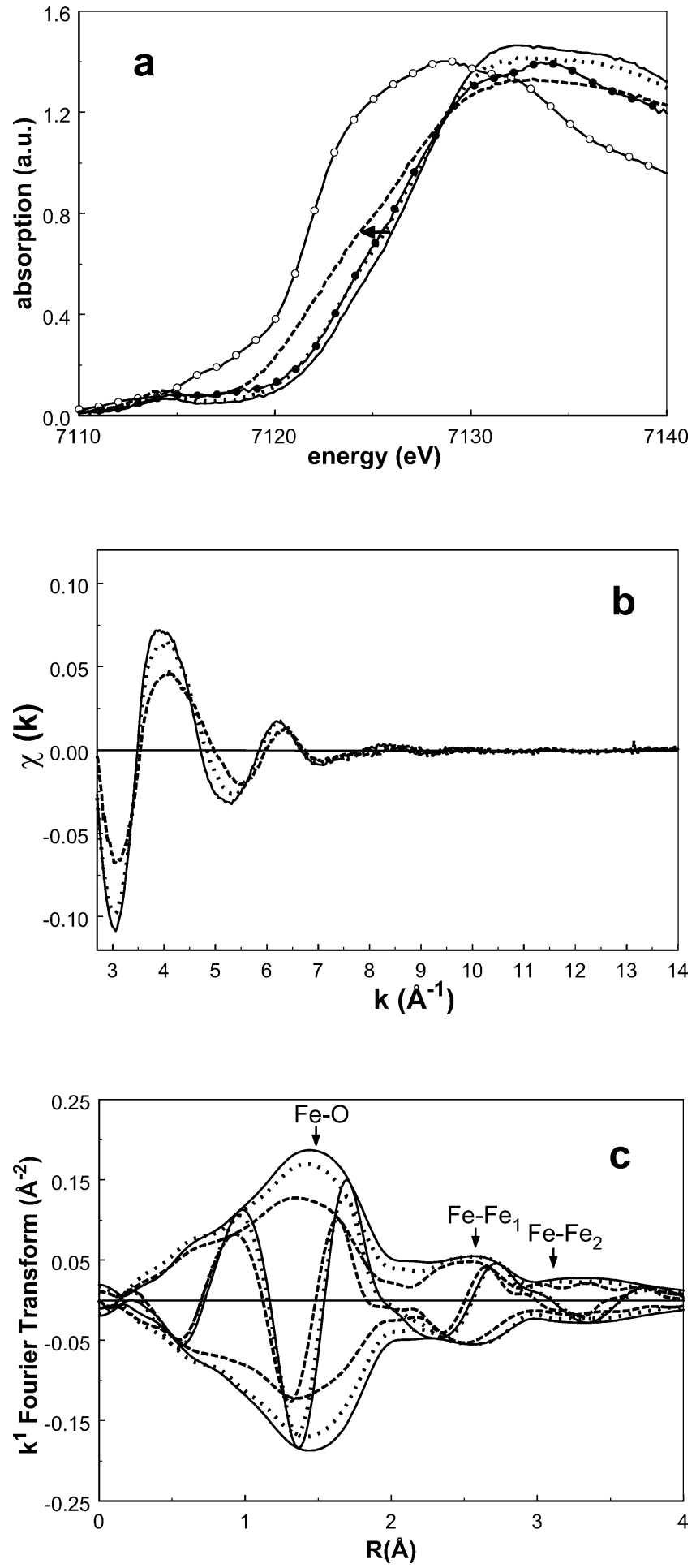

Fig. 3. (a) Normalized XANES spectra of $\mathrm{Fe} / \mathrm{ZSM} 5-\mathrm{He} 30^{\circ} \mathrm{C} / \mathrm{LN}$ (solid line), $\mathrm{Fe} / \mathrm{ZSM} 5-\mathrm{He} 120^{\circ} \mathrm{C} / \mathrm{LN}$ (dotted line), $\mathrm{Fe} / \mathrm{ZSM} 5-\mathrm{He} 350^{\circ} \mathrm{C} / \mathrm{LN}$ (dashed line). Sample $\mathrm{Fe} / \mathrm{ZSM} 5-\mathrm{He} 350^{\circ} \mathrm{C} / \mathrm{LN}$ was measured after $120 \mathrm{~min}$ stabilization in $\mathrm{He}$ at $350^{\circ} \mathrm{C}$. Normalized XANES spectra of hematite $(\bullet$, solid line $)$ and $\mathrm{Fe}$-titanate $(\mathrm{O}$, solid line) are also reported, respectively, as internal $\mathrm{Fe}^{\mathrm{III}}$ and $\mathrm{Fe}^{\mathrm{II}}$ references. (b) Experimental $\chi(k)$ data measured as a function of the heat treatment in He: Fe/ZSM5-He $30^{\circ} \mathrm{C} / \mathrm{LN}$ (solid line), Fe/ZSM5-He $120^{\circ} \mathrm{C} / \mathrm{LN}$ (dotted line), $\mathrm{Fe} / \mathrm{ZSM} 5-\mathrm{He} 350^{\circ} \mathrm{C} / \mathrm{LN}$ (dashed line). (c) Fourier transform $\left(k^{1}, \Delta k=2.7-13.2 \AA^{-1}\right)$ of EXAFS data of $\mathrm{Fe} / \mathrm{ZSM} 5-\mathrm{He} 30^{\circ} \mathrm{C} / \mathrm{LN}$ (solid line), $\mathrm{Fe} / \mathrm{ZSM} 5-\mathrm{He} 120^{\circ} \mathrm{C} / \mathrm{LN}$ (dotted line), and $\mathrm{Fe} / \mathrm{ZSM} 5-\mathrm{He}$ $350^{\circ} \mathrm{C} / \mathrm{LN}$ (dashed line).
Table 3

Coordination parameters obtained by $R$-space analysis $\left(k^{1}, \Delta k=2.7-13.2\right.$ $\AA^{-1} ; \Delta R=0.7-4.2 \AA$ ) of EXAFS data of Fe/ZSM5-He $30^{\circ} \mathrm{C} / \mathrm{LN}$

\begin{tabular}{llllll}
\hline Shells & $N$ & $R(\AA)$ & $\Delta \sigma^{2}\left(10^{-3} \AA^{2}\right)$ & $\Delta E_{0}(\mathrm{eV})$ & $k^{1}$-Variance $(\%)$
\end{tabular} \begin{tabular}{ccccc}
$( \pm 10 \%)( \pm 1 \%)$ & $( \pm 5 \%)$ & $( \pm 10 \%)$ & Im. part & Abs. part \\
\hline Fe/ZSM5-He $30^{\circ} \mathrm{C} / \mathrm{LN}(\operatorname{model} 2: 2: 2)$ & 0.46 & 0.41
\end{tabular}

$\begin{array}{lllll}\mathrm{Fe}-\mathrm{O}_{1} & 1.9 & 1.86 & -3.9 & 0.5\end{array}$

$\mathrm{Fe}-\mathrm{O}_{2} \quad 2.0 \quad 1.97 \quad-5.0 \quad 13.4$

$\begin{array}{lllll}\mathrm{Fe}-\mathrm{O}_{3} & 2.1 & 2.09 & -1.0 & -6.8\end{array}$

$\begin{array}{lllll}\mathrm{Fe}_{-}-\mathrm{Fe}_{1} & 1.2 & 3.05 & 5.9 & -3.2\end{array}$

$\mathrm{Fe}^{-\mathrm{Fe}_{2}} \quad 0.4 \quad 3.40 \quad 14.2 \quad-5.5$

$\begin{array}{lllll}\mathrm{Fe}-\mathrm{O}_{z} & 4.5 & 4.01 & 15.0 & -5.0\end{array}$

Fe/ZSM5-He $30^{\circ} \mathrm{C} / \mathrm{LN}$ (model 3:3)

$0.38 \quad 0.36$

$\begin{array}{lllll}\mathrm{Fe}-\mathrm{O}_{1} & 3.0 & 1.90 & 9.6 & 12.0\end{array}$

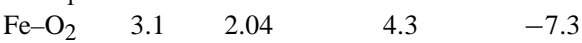

$\begin{array}{lllll}\mathrm{Fe}-\mathrm{Fe}_{1} & 1.2 & 3.06 & 5.4 & -3.6\end{array}$

$\begin{array}{lllll}\mathrm{Fe}-\mathrm{Fe}_{2} & 0.4 & 3.40 & 10.7 & -8.0\end{array}$

$\begin{array}{lllll}\mathrm{Fe}-\mathrm{O}_{z} & 4.7 & 4.11 & 11.7 & -6.6\end{array}$

Model (2:2:2): $N_{\text {indp }}=25.4 ; N_{\text {free (fit) }}=22$.

Model (3:3): $N_{\text {indp }}=25.4 ; N_{\text {free }(\text { fit })}=18$.

local environment of iron. These changes are also revealed in the corresponding Fourier transforms of the experimental EXAFS data (Fig. 3c). Three main peaks are visible, centered, respectively, at around $1.5 \AA$ ( $\mathrm{Fe}-\mathrm{O}$, in the picture), $2.6 \AA\left(\mathrm{Fe}-\mathrm{Fe}_{1}\right)$, and $3.1 \AA\left(\mathrm{Fe}-\mathrm{Fe}_{2}\right)$. It can be seen that the largest changes occur after heating in $\mathrm{He}$ at temperatures higher than $120^{\circ} \mathrm{C}$. Large changes can be observed in the $\mathrm{Fe}-\mathrm{O}$ shells region in the range $1.0<R<2.0 \AA$. Also the $\mathrm{Fe}-\mathrm{Fe}_{1}$ shell is influenced.

The EXAFS coordination parameters obtained by the $R$-space fitting procedure for sample $\mathrm{Fe} / \mathrm{ZSM} 5-\mathrm{He} 30^{\circ} \mathrm{C} /$ $\mathrm{LN}$ are collected in Table 3. For the $R$-space fit the Fourier transform range was taken from 2.7 to $13.2 \AA^{-1}$ with a range in $R$ space from 0.7 to $4.2 \AA$. The number of independent parameters was calculated to be $N_{\text {indp }}=25.4$. Consistently with the results obtained by HR-XANES on Fe/ZSM5 measured at $30^{\circ} \mathrm{C}$, the fit of the $\mathrm{Fe}-\mathrm{O}$ contribution revealed the presence of six oxygen neighbors. A good quality fit could be obtained with two different oxygen distributions, i.e., by using two oxygen shells (model 3:3) or three oxygen shells (model 2:2:2). The total number of fit parameters was 18 and 22, respectively. No significant difference was obtained in the statistical variance of the two fits. It should be noted that for both models the fits were optimized by including distant oxygen neighbors, attributed to the zeolite framework $\left(\mathrm{Fe}-\mathrm{O}_{z}\right)$. No further implications for a structural model were derived from this $\mathrm{Fe}-\mathrm{O}_{z}$ contribution, added to the fit in order to analyze more reliably shell $\mathrm{Fe}-\mathrm{Fe}_{2}$ (vide infra).

The second peak of the Fourier transform $\left(\mathrm{Fe}-\mathrm{Fe}_{1}\right)$ was fitted with a $\mathrm{Fe}-\mathrm{Fe}$ shell at $3.05 \AA$ with a coordination number of 1.2. This shell is ascribed to the presence of binuclear Fe complexes [25]. The fact that the coordination number of this shell is higher than 1.0 and that an additional $\mathrm{Fe}-\mathrm{Fe}_{2}$ shell could be fitted at higher distances $(R=3.40 \AA$, 


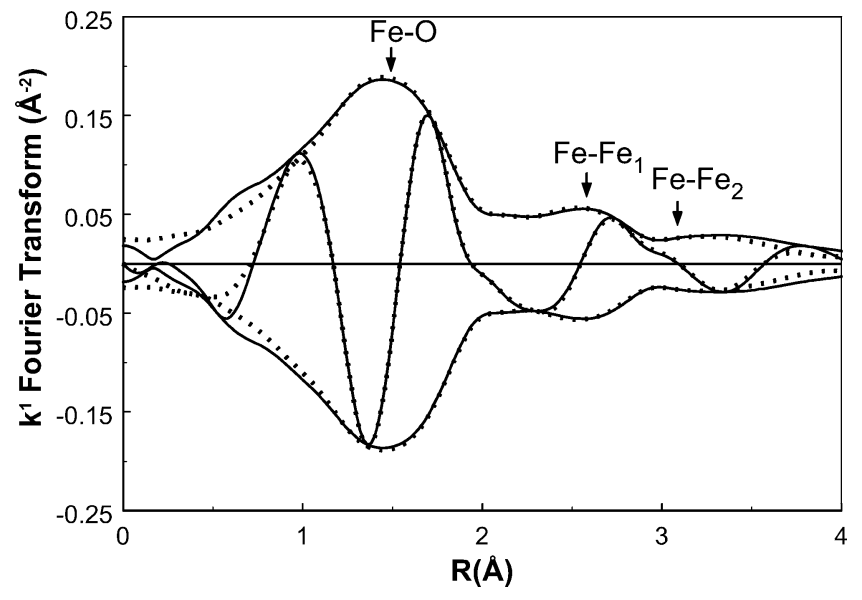

Fig. 4. Fourier transform $\left(k^{1}, \Delta k=2.7-13.2 \AA^{-1}\right)$ of EXAFS data of $\mathrm{Fe} / \mathrm{ZSM} 5-\mathrm{He} 30^{\circ} \mathrm{C} / \mathrm{LN}$ (solid line) and $R$-space fit (dotted line; $0.7<R$ $(\AA)<4.2$; fit-model 2:2:2).

$N=0.4$ ), as already discussed in [25], is the result of further agglomeration of a fraction of iron. From the EXAFS coordination numbers of the Fe-Fe shells, binuclear clusters in sample Fe/ZSM5 are estimated to account for at least $70 \%$ of the total iron [25]. The quality of $R$-space fit using the 2:2:2 model is demonstrated in Fig. 4 for the Fe/ZSM5 sample treated in $\mathrm{He}$ at $30^{\circ} \mathrm{C}$ RT and measured at L.N. temperature.

The results obtained during the heat treatments can be best described and understood in terms of the 2:2:2 model. The reactivity of the Fe/ZSM5 sample, using the $2: 2: 2$ model, is visualized in changes in the number of oxygen neighbors in the $\mathrm{Fe}-\mathrm{O}_{1}$ and $\mathrm{Fe}-\mathrm{O}_{3}$ coordination.

The results of the $R$-space fits of measurements $\mathrm{Fe} /$ ZSM5-He $30^{\circ} \mathrm{C} / \mathrm{LN}, \mathrm{Fe} / \mathrm{ZSM} 5-\mathrm{He} 120^{\circ} \mathrm{C} / \mathrm{LN}$, and $\mathrm{Fe} /$ ZSM5-He $350^{\circ} \mathrm{C} / \mathrm{LN}$, using the $2: 2: 2$ model, are summarized in Table 4. It can be seen that the coordination number of the $\mathrm{Fe}-\mathrm{O}_{3}$ coordination significantly decreases with increasing temperature from $2.1\left(30^{\circ} \mathrm{C}\right)$ to $1.4\left(120^{\circ}\right)$, and to $0.9\left(350^{\circ} \mathrm{C}\right)$. As a result, the imaginary part of the total $\mathrm{Fe}-\mathrm{O}$ contribution appears to be shifted toward lower $R$ (Fig. 3c). Since the EXAFS analysis showed already a decrease in the coordination number of the $\mathrm{Fe}-\mathrm{O}_{3}$ shell at $120^{\circ} \mathrm{C}$ (Fe-oxidation state is III), the oxygen located in this shell cannot be responsible for red-ox behavior of iron. The $\mathrm{Fe}-\mathrm{O}_{3}$ shell is therefore attributed to weakly bound oxygen, most probably of $\mathrm{H}_{2} \mathrm{O}$. Besides a further decrease in the oxygen coordination number, an increase in the disorder $\left(\Delta \sigma^{2}\right)$ and a change in the inner potential value $\left(\Delta E_{0}\right)$ of the $\mathrm{Fe}-\mathrm{O}_{3}$ shell is observed when heating from 120 to $350{ }^{\circ} \mathrm{C}$. At the same time a small decrease is visible in the coordination number of the $\mathrm{Fe}-\mathrm{O}_{1}$ shell. The decrease of the oxygen coordination number of the $\mathrm{Fe}-\mathrm{O}_{3}$ shell as a function of the He treatment is visualized in Fig. 5. No changes are observed for the $\mathrm{Fe}-\mathrm{O}_{2}$ shell during the heat treatment in $\mathrm{He}$.

Also a change in the distance of the $\mathrm{Fe}-\mathrm{Fe}_{1}$ is observed when heating from 120 to $350^{\circ} \mathrm{C}$, indicating a shortening in
Table 4

Coordination parameters (model 2:2:2) obtained by $R$-space analysis $\left(k^{1}\right.$, $\Delta k=2.7-13.2 \AA^{-1} ; \Delta R=0.7-4.2 \AA$ ) of EXAFS data of Fe/ZSM5-He $30^{\circ} \mathrm{C} / \mathrm{LN}, \mathrm{Fe} / \mathrm{ZSM} 5-\mathrm{He} 120^{\circ} \mathrm{C} / \mathrm{LN}$, and Fe/ZSM5-He $350^{\circ} \mathrm{C} / \mathrm{LN}$

\begin{tabular}{|c|c|c|c|c|c|c|}
\hline \multirow[t]{2}{*}{ Shells } & \multirow{2}{*}{$\begin{array}{c}N \\
( \pm 10 \%) \\
\end{array}$} & $R(\AA)$ & $\Delta \sigma^{2}\left(10^{-3} \AA^{2}\right)$ & $\Delta E_{0}(\mathrm{eV})$ & \multicolumn{2}{|c|}{$k^{1}$-Variance $(\%)$} \\
\hline & & $( \pm 1 \%)$ & $( \pm 5 \%)$ & $( \pm 10 \%)$ & Im. part & Abs. part \\
\hline \multicolumn{5}{|c|}{$\mathrm{Fe} / \mathrm{ZSM} 5-\mathrm{He} 30^{\circ} \mathrm{C} / \mathrm{LN}$} & 0.46 & 0.41 \\
\hline $\mathrm{Fe}-\mathrm{O}_{1}$ & 1.9 & 1.86 & -3.9 & 0.5 & & \\
\hline $\mathrm{Fe}-\mathrm{O}_{2}$ & 2.0 & 1.97 & -5.0 & 13.4 & & \\
\hline $\mathrm{Fe}-\mathrm{O}_{3}$ & 2.1 & 2.09 & -1.0 & -6.8 & & \\
\hline $\mathrm{Fe}-\mathrm{Fe}_{1}$ & 1.2 & 3.05 & 5.9 & -3.2 & & \\
\hline $\mathrm{Fe}-\mathrm{Fe}_{2}$ & 0.4 & 3.40 & 14.2 & -5.5 & & \\
\hline $\mathrm{Fe}-\mathrm{O}$ & 4.5 & 4.01 & 5.0 & -5.0 & & \\
\hline
\end{tabular}

$\mathrm{Fe} / \mathrm{ZSM} 5-\mathrm{He} 120^{\circ} \mathrm{C} / \mathrm{LN}$

0.49

0.37

\begin{tabular}{|c|c|c|c|c|c|c|}
\hline $\mathrm{Fe}-\mathrm{O}_{1}$ & 2.0 & 1.85 & -3.9 & 0.5 & & \\
\hline $\mathrm{Fe}-\mathrm{O}_{2}$ & 2.0 & 1.97 & -5.0 & 13.4 & & \\
\hline $\mathrm{Fe}-\mathrm{O}_{3}$ & 1.4 & 2.09 & -2.2 & -6.8 & & \\
\hline $\mathrm{Fe}-\mathrm{Fe}_{1}$ & 1.2 & 3.05 & 2.9 & -3.2 & & \\
\hline $\mathrm{Fe}-\mathrm{Fe}_{2}$ & 0.4 & 3.40 & 14.2 & -5.5 & & \\
\hline $\mathrm{Fe}-\mathrm{O}_{z}$ & 4.5 & 4.01 & 15.0 & -5.0 & & \\
\hline \multicolumn{5}{|c|}{$\mathrm{Fe} / \mathrm{ZSM} 5-\mathrm{He} 350^{\circ} \mathrm{C} / \mathrm{LN}$} & 0.58 & 0.55 \\
\hline $\mathrm{Fe}-\mathrm{O}_{1}$ & 1.8 & 1.85 & -3.5 & -1.8 & & \\
\hline $\mathrm{Fe}-\mathrm{O}_{2}$ & 2.0 & 1.97 & -4.3 & 12.6 & & \\
\hline $\mathrm{Fe}-\mathrm{O}_{3}$ & 0.9 & 2.08 & 2.2 & -11.1 & & \\
\hline $\mathrm{Fe}-\mathrm{Fe}_{1}$ & 1.2 & 2.97 & 1.3 & 1.8 & & \\
\hline $\mathrm{Fe}-\mathrm{Fe}_{2}$ & 0.4 & 3.40 & 15.0 & -5.5 & & \\
\hline $\mathrm{Fe}-\mathrm{O}_{z}$ & 3.2 & 3.99 & 15.0 & -4.9 & & \\
\hline
\end{tabular}
$N_{\text {indp }}=25.4 ; N_{\text {free (fit) }}=22$.

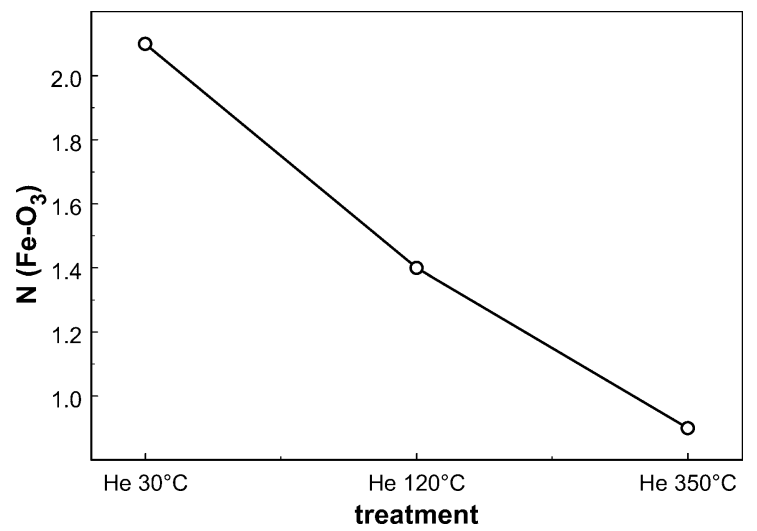

Fig. 5. Average number of oxygen atoms in the $\mathrm{Fe}-\mathrm{O}_{3}$ coordination shell (model 2:2:2) as a function of heat treatment in $\mathrm{He}$.

the $\mathrm{Fe}-\mathrm{Fe}$ distance of the binuclear Fe complexes $(2.97 \AA$ in $\mathrm{He}$ at $350^{\circ} \mathrm{C}$ ). During the fitting process, the coordination number and distance of the $\mathrm{Fe}-\mathrm{Fe}_{2}$ shell were fixed to the values obtained for measurement Fe/ZSM5-He $30^{\circ} \mathrm{C} / \mathrm{LN}$ (model 3:3). $\mathrm{Fe}-\mathrm{Fe}_{2}$ is a minor contribution and no important information was derived from this shell for the autoreduction properties of the Fe/ZSM5 sample.

\subsubsection{Stabilization in $\mathrm{He}$ at $350^{\circ} \mathrm{C}$}

The results presented above for the He treatment at $350{ }^{\circ} \mathrm{C}$ were obtained after $120 \mathrm{~min}$ stabilization on stream and after cooling the Fe/ZSM5 sample to liquid nitrogen 

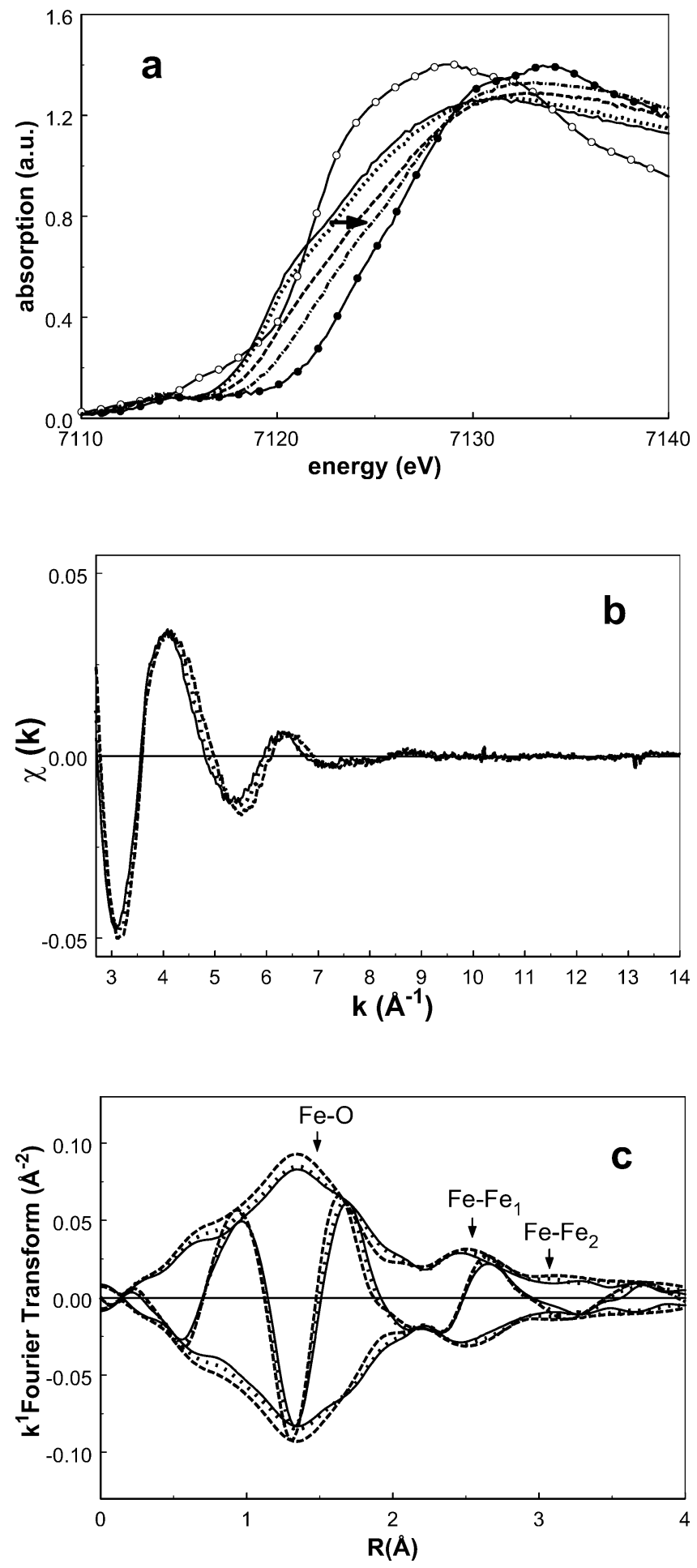

Fig. 6. (a) Normalized XANES spectra of Fe/ZSM5-He $350{ }^{\circ} \mathrm{C}$ (1st)/ $350^{\circ} \mathrm{C}$ (solid line), $\mathrm{Fe} / \mathrm{ZSM} 5-\mathrm{He} 350^{\circ} \mathrm{C}(2 \mathrm{nd}) / 350^{\circ} \mathrm{C}$ (dotted line), $\mathrm{Fe} /$ ZSM5-He $350^{\circ} \mathrm{C}(3 \mathrm{rd}) / 350^{\circ} \mathrm{C}$ (dashed line), and Fe/ZSM5-He $350^{\circ} \mathrm{C} /$ LN (dashed-dotted line). Normalized XANES spectra of hematite $(\bullet$, solid line $)$ and $\mathrm{Fe}$-titanate $(\mathrm{O}$, solid line $)$ are reported as internal $\mathrm{Fe}^{\mathrm{III}}$ and $\mathrm{Fe}^{\mathrm{II}}$ references. (b) Experimental $\chi(k)$ data of $\mathrm{Fe} / \mathrm{ZSM} 5-\mathrm{He} 350^{\circ} \mathrm{C}$ (1st) $/ 350^{\circ} \mathrm{C}$ (solid line), Fe/ZSM5-He $350{ }^{\circ} \mathrm{C}(2 \mathrm{nd}) / 350{ }^{\circ} \mathrm{C}$ (dotted line), $\mathrm{Fe} / \mathrm{ZSM} 5-\mathrm{He} 350^{\circ} \mathrm{C}(3 \mathrm{rd}) / 350^{\circ} \mathrm{C}$ (dashed line). (c) Fourier transform $\left(k^{1}, \Delta k=2.7-13.2 \AA^{-1}\right)$ of EXAFS data of $\mathrm{Fe} / \mathrm{ZSM} 5-\mathrm{He} 350^{\circ} \mathrm{C}$ (1st) $/ 350{ }^{\circ} \mathrm{C}$ (solid line), $\mathrm{Fe} / \mathrm{ZSM} 5-\mathrm{He} 350^{\circ} \mathrm{C}(2 \mathrm{nd}) / 350{ }^{\circ} \mathrm{C}$ (dotted line), $\mathrm{Fe} / \mathrm{ZSM} 5-\mathrm{He} 350^{\circ} \mathrm{C}$ (3rd) $/ 350^{\circ} \mathrm{C}$ (dashed line). temperature. However, very important changes occurred during this stabilization period. The HR-XANES results (Fig. 1b) already showed that, after reaching $350^{\circ} \mathrm{C}$ in $\mathrm{He}$, the oxidation state of $\mathrm{Fe}$ is close to 2.4. The XANES spectra recorded in situ at $350^{\circ} \mathrm{C}$ are depicted in Fig. 6a. The figure shows a clear shift to lower energy of the edge position of spectrum $\mathrm{Fe} / \mathrm{ZSM} 5-\mathrm{He} 350^{\circ} \mathrm{C}(1 \mathrm{st}) / 350^{\circ} \mathrm{C}$, recorded after 30 min stabilization. This confirms that heating Fe/ZSM5 in He to $350^{\circ} \mathrm{C}$ results in the reduction of a significant fraction of iron. However, the state of iron under $\mathrm{He}$ at $350^{\circ} \mathrm{C}$ appeared to be unstable. This is visible by tracking the shift of the edge position with time on stream (measurements 1st, 2nd and 3rd). A significant shift ( $+2 \mathrm{eV})$ occurred, showing an average reoxidation of iron.

The effect of the reoxidation process on the local structure of iron can be tracked by the analysis of the EXAFS data collected in situ in $\mathrm{He}$ at $350^{\circ} \mathrm{C}$. The EXAFS spectra obtained respectively after 30,60 , and $90 \mathrm{~min}$ exposure to $\mathrm{He}$ are shown in Fig. 6b. It can be seen that both the amplitude and the nodes of the EXAFS oscillations are changing as a function of the stabilization period. The corresponding Fourier transforms are presented in Fig. 6c. The $\mathrm{Fe}-\mathrm{O}$ contribution shows an increase with time on stream of its maximum intensity (at around $1.4 \AA$ in the picture) accompanied by a contraction toward lower distance. No significant differences are visible, on the contrary, in the $\mathrm{Fe}-\mathrm{Fe}$ contribution.

Table 5 shows the results of the EXAFS fit, performed on $\mathrm{Fe} / \mathrm{ZSM} 5$ measured in situ at $350^{\circ} \mathrm{C}$ during the stabilization in He. The most significant changes with time on stream occurred in the coordination number of the $\mathrm{Fe}-\mathrm{O}_{1}$ shell. The coordination number increased from 1.2 (1st scan) to 1.7 (3rd scan). As already deduced from the XANES spectra (Fig. 6a), this increase was accompanied by a corresponding partial oxidation of iron. The $\mathrm{Fe}-\mathrm{O}_{1}$ shell is therefore associated with the red-ox properties of the Febinuclear complexes. The decrease with time on stream of the coordination number of the $\mathrm{Fe}-\mathrm{O}_{3}$ shell, which was already shown not to be related to red-ox properties of iron (previous section), is most probably due to further desorption of water from the coordination sphere of iron. No differences were visible in the $\mathrm{Fe}-\mathrm{O}_{2}$ shell.

\subsubsection{Heat treatment in $\mathrm{O}_{2}$}

The influence of the oxygen presence on the reducibility of iron during the heat treatment can be seen in Fig. 7a, by comparing the XANES spectra of $\mathrm{Fe} / \mathrm{ZSM} 5-\mathrm{He} 350^{\circ} \mathrm{C}$ (1st) $/ 350{ }^{\circ} \mathrm{C}$ and $\mathrm{Fe} / \mathrm{ZSM} 5-\mathrm{O}_{2} 350^{\circ} \mathrm{C} / 350^{\circ} \mathrm{C}$. As can be seen, the edge position of the sample heated in He (after 30 min stabilization) appears to be close to the edge of $\mathrm{Fe}-$ titanate $\left(\mathrm{Fe}^{\mathrm{II}}\right)$, while the edge position of $\mathrm{Fe} / \mathrm{ZSM} 5$ heated in oxygen corresponds to that of the hematite reference $\left(\mathrm{Fe}^{\mathrm{III}}\right)$. Thus, oxygen prevented the auto-reduction of iron.

The XAFS spectra in the presence of oxygen were measured in situ $\left(\mathrm{Fe} / \mathrm{ZSM} 5-\mathrm{O}_{2} 350 \mathrm{C} / 350^{\circ}\right.$ and after cooling to $77 \mathrm{~K}\left(\mathrm{Fe} / \mathrm{ZSM} 5-\mathrm{O}_{2} 350^{\circ} \mathrm{C} / \mathrm{LN}\right)$. Differently from what 
Table 5

Coordination parameters (model 2:2:2) obtained by $R$-space analysis $\left(k^{1}\right.$, $\left.\Delta k=2.7-13.2 \AA^{-1} ; \Delta R=0.7-4.2 \AA\right)$ of EXAFS data of Fe/ZSM5$\mathrm{He} 350^{\circ} \mathrm{C}$ (1st) $/ 350^{\circ} \mathrm{C}$, Fe/ZSM5-He $350{ }^{\circ} \mathrm{C}$ (2nd) $/ 350{ }^{\circ} \mathrm{C}$, Fe/ZSM5$\mathrm{He} 350^{\circ} \mathrm{C}(3 \mathrm{rd}) / 350{ }^{\circ} \mathrm{C}$, and Fe/ZSM5-He $350^{\circ} \mathrm{C} / \mathrm{LN} ; N_{\text {indp }}=25.4$; $N_{\text {free (fit) }}=22$

\begin{tabular}{|c|c|c|c|c|c|c|}
\hline \multirow[t]{2}{*}{ Shells } & \multirow{2}{*}{$\begin{array}{c}N \\
( \pm 10 \%) \\
\end{array}$} & \multirow{2}{*}{$\begin{array}{l}R(\AA) \\
( \pm 1 \%) \\
\end{array}$} & \multirow{2}{*}{$\begin{array}{c}\Delta \sigma^{2}\left(10^{-3} \AA^{2}\right) \\
( \pm 5 \%)\end{array}$} & \multirow{2}{*}{$\begin{array}{c}\Delta E_{0}(\mathrm{eV}) \\
( \pm 10 \%)\end{array}$} & \multicolumn{2}{|c|}{$k^{1}$-Variance $(\%)$} \\
\hline & & & & & Im. part & Abs. part \\
\hline \multicolumn{5}{|c|}{$\mathrm{Fe} / \mathrm{ZSM} 5-\mathrm{He} 350^{\circ} \mathrm{C}(1 \mathrm{st}) / 350^{\circ} \mathrm{C}$} & 0.55 & 0.30 \\
\hline $\mathrm{Fe}-\mathrm{O}_{1}$ & 1.2 & 1.88 & 2.6 & -5.5 & & \\
\hline $\mathrm{Fe}-\mathrm{O}_{2}$ & 2.0 & 1.97 & 7.2 & 12.6 & & \\
\hline $\mathrm{Fe}-\mathrm{O}_{3}$ & 1.2 & 2.08 & 8.8 & -9.3 & & \\
\hline $\mathrm{Fe}-\mathrm{Fe}_{1}$ & 1.1 & 2.99 & 13.0 & 0.4 & & \\
\hline $\mathrm{Fe}-\mathrm{Fe}_{2}$ & 0.4 & 3.40 & 17.2 & 0.1 & & \\
\hline $\mathrm{Fe}-\mathrm{O}_{z}$ & 1.6 & 4.09 & 15.0 & -8.8 & & \\
\hline
\end{tabular}

$\mathrm{Fe} / \mathrm{ZSM} 5-\mathrm{He} 350^{\circ} \mathrm{C}(2 \mathrm{nd}) / 350^{\circ} \mathrm{C}$

$0.67 \quad 0.39$

$\begin{array}{lllrr}\mathrm{Fe}-\mathrm{O}_{1} & 1.4 & 1.88 & 2.6 & -5.5 \\ \mathrm{Fe}-\mathrm{O}_{2} & 2.0 & 1.97 & 7.2 & 12.6 \\ \mathrm{Fe}-\mathrm{O}_{3} & 1.1 & 2.08 & 8.8 & -9.3 \\ \mathrm{Fe}-\mathrm{Fe}_{1} & 1.1 & 2.99 & 13.0 & 0.4 \\ \mathrm{Fe}-\mathrm{Fe}_{2} & 0.4 & 3.40 & 13.8 & 1.5 \\ \mathrm{Fe}-\mathrm{O}_{z} & 2.2 & 4.00 & 15.0 & -7.2\end{array}$

$\mathrm{Fe} / \mathrm{ZSM} 5-\mathrm{He} 350^{\circ} \mathrm{C}(3 \mathrm{rd}) / 350^{\circ} \mathrm{C}$

$-7.2$

\begin{tabular}{|c|c|c|c|c|c|c|}
\hline \multicolumn{5}{|c|}{$\mathrm{Fe} / \mathrm{ZSM} 5-\mathrm{He} 350^{\circ} \mathrm{C}(3 \mathrm{rd}) / 350^{\circ} \mathrm{C}$} & \multirow[t]{7}{*}{0.94} & \multirow[t]{7}{*}{0.47} \\
\hline $\mathrm{Fe}-\mathrm{O}_{1}$ & 1.7 & 1.89 & 1.9 & -6.5 & & \\
\hline $\mathrm{Fe}-\mathrm{O}_{2}$ & 2.0 & 1.97 & 7.2 & 12.6 & & \\
\hline $\mathrm{Fe}-\mathrm{O}_{3}$ & 0.7 & 2.06 & 2.0 & -8.7 & & \\
\hline $\mathrm{Fe}-\mathrm{Fe}_{1}$ & 1.2 & 2.97 & 12.5 & -0.4 & & \\
\hline $\mathrm{Fe}-\mathrm{Fe}_{2}$ & 0.4 & 3.40 & 14.8 & 3.1 & & \\
\hline $\mathrm{Fe}-\mathrm{O}_{z}$ & 3.7 & 3.91 & 18.0 & -2.2 & & \\
\hline \multicolumn{5}{|c|}{$\mathrm{Fe} / \mathrm{ZSM} 5-\mathrm{He} 350^{\circ} \mathrm{C} / \mathrm{LN}$} & 0.58 & 0.55 \\
\hline $\mathrm{Fe}-\mathrm{O}_{1}$ & 1.8 & 1.85 & -3.5 & -1.8 & & \\
\hline $\mathrm{Fe}-\mathrm{O}_{2}$ & 2.0 & 1.97 & -4.3 & 12.6 & & \\
\hline $\mathrm{Fe}-\mathrm{O}_{3}$ & 0.9 & 2.08 & 2.2 & -11.1 & & \\
\hline $\mathrm{Fe}-\mathrm{Fe}_{1}$ & 1.2 & 2.97 & 1.3 & 1.8 & & \\
\hline $\mathrm{Fe}-\mathrm{Fe}_{2}$ & 0.4 & 3.40 & 15.0 & -5.5 & & \\
\hline $\mathrm{Fe}-\mathrm{O}_{z}$ & 3.2 & 3.99 & 15.0 & -4.9 & & \\
\hline
\end{tabular}

observed under helium, the three EXAFS spectra recorded in oxygen at high temperatures at increasing exposure time appeared to be identical and were therefore averaged. Significant differences are visible when comparing the EXAFS functions of $\mathrm{Fe} / \mathrm{ZSM} 5$ measured in situ at $350^{\circ} \mathrm{C}$ in oxygen, and in helium after 30 min stabilization (Fig. 7b). The corresponding Fourier transforms, collected in Fig. 7c, show that these differences concern mainly the $\mathrm{Fe}-\mathrm{O}$ coordination. In the presence of oxygen, the $\mathrm{Fe}-\mathrm{O}$ peak appears significantly enhanced in intensity and shifted towards lower $R$.

The structural parameters obtained by the analysis of the EXAFS spectra recorded in the presence of oxygen are collected in Table 6. Apart from differences in the Debye-Waller factors (temperature effects), the results of the fits $\left(\mathrm{Fe} / \mathrm{ZSM} 5-\mathrm{O}_{2} 350^{\circ} \mathrm{C} / 350^{\circ} \mathrm{C}\right.$ and $\mathrm{Fe} / \mathrm{ZSM} 5-\mathrm{O}_{2}$ $350{ }^{\circ} \mathrm{C} / \mathrm{LN}$ ) coincide. The total $\mathrm{Fe}-\mathrm{O}$ coordination number (around 5.0) appears to be consistent with the results obtained by HR-XANES (see Fig. $2 \mathrm{~b}\left(\mathrm{O}_{2}, 350^{\circ} \mathrm{C}\right)$ ). When compared to the sample measured at $350^{\circ}$ in $\mathrm{He}$ after 30 min stabilization (see Table 5), a sharp increase was detected in the coordination number of shell $\mathrm{Fe}-\mathrm{O}_{1}$ (1.9 vs
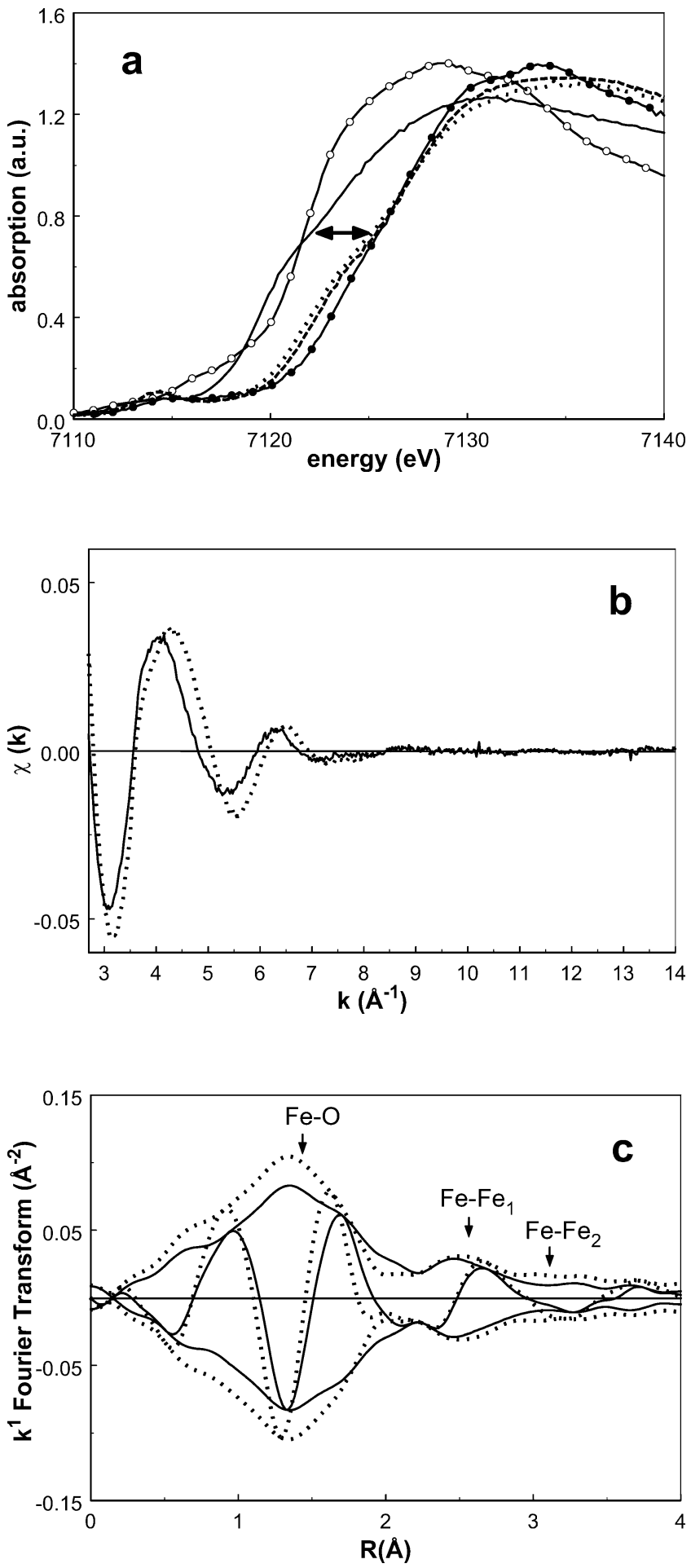

Fig. 7. (a) Normalized XANES spectra of $\mathrm{Fe} / \mathrm{ZSM} 5-\mathrm{He} 350^{\circ} \mathrm{C}$ (1st) $/ 350{ }^{\circ} \mathrm{C}$ (solid line), $\mathrm{Fe} / \mathrm{ZSM} 5-\mathrm{O}_{2} 350^{\circ} \mathrm{C} / 350^{\circ} \mathrm{C}$ (dotted line), and $\mathrm{Fe} / \mathrm{ZSM} 5-\mathrm{O}_{2} 350^{\circ} \mathrm{C} / \mathrm{LN}$ (dashed line). Normalized XANES spectra of hematite $(\bullet$, solid line) and $\mathrm{Fe}-$ titanate $(\mathrm{O}$, solid line) are reported as internal $\mathrm{Fe}^{\mathrm{III}}$ and $\mathrm{Fe}^{\mathrm{II}}$ references. (b) Experimental $\chi(k)$ data of $\mathrm{Fe} / \mathrm{ZSM} 5-\mathrm{He}$ $350{ }^{\circ} \mathrm{C}(1 \mathrm{st}) / 350^{\circ} \mathrm{C}$ (solid line) and $\mathrm{Fe} / \mathrm{ZSM} 5-\mathrm{O}_{2} 350^{\circ} \mathrm{C} / 350{ }^{\circ} \mathrm{C}$ (dotted line). Note that the XAFS spectra of $\mathrm{Fe} / \mathrm{ZSM} 5$ recorded at $350^{\circ} \mathrm{C}$ in the presence of oxygen did not reveal any difference with time on stream. (c) Fourier transform $\left(k^{1}, \Delta k=2.7-13.2 \AA^{-1}\right)$ of EXAFS data of $\mathrm{Fe} / \mathrm{ZSM} 5-\mathrm{He} 350^{\circ} \mathrm{C}(1 \mathrm{st}) / 350^{\circ} \mathrm{C}$ (solid line) and $\mathrm{Fe} / \mathrm{ZSM} 5-\mathrm{O}_{2}$ $350{ }^{\circ} \mathrm{C} / 350^{\circ} \mathrm{C}$ (dotted line). 
Table 6

Coordination parameters (model 2:2:2) obtained by $R$-space analysis $\left(k^{1}\right.$, $\Delta k=2.7-13.2 \AA^{-1} ; \Delta R=0.7-4.2 \AA$ ) of EXAFS data of Fe $/ \mathrm{ZSM}_{5}-\mathrm{O}_{2}$ $350{ }^{\circ} \mathrm{C} / 350{ }^{\circ} \mathrm{C}$, and $\mathrm{Fe} / \mathrm{ZSM} 5-\mathrm{O}_{2} 350^{\circ} \mathrm{C} / \mathrm{LN}$

\begin{tabular}{|c|c|c|c|c|c|c|}
\hline \multirow[t]{2}{*}{ Shells } & \multirow{2}{*}{$\begin{array}{c}N \\
( \pm 10 \%)\end{array}$} & \multirow{2}{*}{$\begin{array}{l}R(\AA) \\
( \pm 1 \%)\end{array}$} & \multirow{2}{*}{$\begin{array}{c}\Delta \sigma^{2}\left(10^{-3} \AA^{2}\right) \\
( \pm 5 \%)\end{array}$} & \multirow{2}{*}{$\begin{array}{c}\Delta E_{0}(\mathrm{eV}) \\
( \pm 10 \%)\end{array}$} & \multicolumn{2}{|c|}{$k^{1}$-Variance $(\%)$} \\
\hline & & & & & Im. part & Abs. part \\
\hline \multicolumn{5}{|c|}{$\mathrm{Fe} / \mathrm{ZSM} 5-\mathrm{O}_{2} 350^{\circ} \mathrm{C} / 350^{\circ} \mathrm{C}$} & 1.26 & 0.50 \\
\hline $\mathrm{Fe}-\mathrm{O}_{1}$ & 1.9 & 1.86 & 2.0 & -2.5 & & \\
\hline $\mathrm{Fe}-\mathrm{O}_{2}$ & 2.0 & 1.99 & 5.0 & 13.0 & & \\
\hline $\mathrm{Fe}-\mathrm{O}_{3}$ & 1.0 & 2.02 & 1.6 & -13.3 & & \\
\hline $\mathrm{Fe}-\mathrm{Fe}_{1}$ & 1.2 & 2.99 & 9.8 & -1.6 & & \\
\hline $\mathrm{Fe}-\mathrm{Fe}_{2}$ & 0.4 & 3.40 & 15.1 & -3.7 & & \\
\hline $\mathrm{Fe}-\mathrm{O}_{z}$ & 4.4 & 3.81 & 15.0 & 1.0 & & \\
\hline \multicolumn{5}{|c|}{$\mathrm{Fe} / \mathrm{ZSM} 5-\mathrm{O}_{2} 350^{\circ} \mathrm{C} / \mathrm{LN}$} & 0.97 & 0.70 \\
\hline $\mathrm{Fe}-\mathrm{O}_{1}$ & 2.0 & 1.85 & -3.8 & -4.3 & & \\
\hline $\mathrm{Fe}-\mathrm{O}_{2}$ & 2.0 & 1.97 & -5.0 & 12.0 & & \\
\hline $\mathrm{Fe}-\mathrm{O}_{3}$ & 1.0 & 2.02 & 4.5 & -6.6 & & \\
\hline $\mathrm{Fe}-\mathrm{Fe}_{1}$ & 1.2 & 2.96 & 2.4 & 2.0 & & \\
\hline $\mathrm{Fe}-\mathrm{Fe}_{2}$ & 0.4 & 3.40 & 15.0 & 0.0 & & \\
\hline $\mathrm{Fe}-\mathrm{Oz}$ & 3.8 & 3.91 & 15.0 & -2.2 & & \\
\hline
\end{tabular}

$N_{\text {indp }}=25.4 ; N_{\text {free (fit) }}=22$.

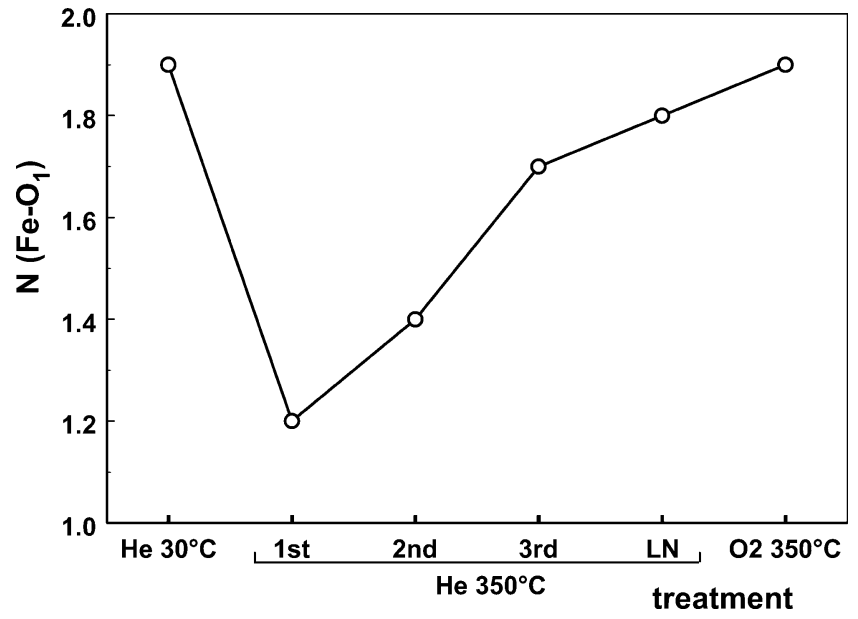

Fig. 8. Number of oxygen atoms in the $\mathrm{Fe}-\mathrm{O}_{1}$ coordination shell (model 2:2:2) as a function of heat treatment in $\mathrm{He}$, and in the presence of $\mathrm{O}_{2}$.

1.2 for $\left.\mathrm{Fe} / \mathrm{ZSM} 5-\mathrm{He} 350{ }^{\circ} \mathrm{C}(1 \mathrm{st}) / 350^{\circ} \mathrm{C}\right)$. The coordination number of shell $\mathrm{Fe}-\mathrm{O}_{3}$, on the contrary, appears only slightly decreased, probably as a result of further water desorption with time on stream (1.0 vs 1.2 , for Fe/ZSM5$\left.\mathrm{He} 350^{\circ} \mathrm{C}(1 \mathrm{st}) / 350{ }^{\circ} \mathrm{C}\right)$. The $\mathrm{Fe}-\mathrm{O}_{3}$ distance appears also to be slightly shortened. Also during the heating treatment in oxygen, the $\mathrm{Fe}-\mathrm{O}_{2}$ shell remained unaffected.

As shown by the results obtained during the heat treatments, changes in the oxidation state of iron are related to variations only in the $\mathrm{Fe}-\mathrm{O}_{1}$ coordination number. A coordination number of approximately 1 corresponds to an average $\mathrm{Fe}$-oxidation state close to II. When the $\mathrm{Fe}-\mathrm{O}_{1}$ coordination number is increased to $2, \mathrm{Fe}$ is completely oxidized $\left(\mathrm{Fe}^{\mathrm{III}}\right)$. The changes in the $\mathrm{Fe}-\mathrm{O}_{1}$ coordination number, as a function of the different treatments, are visualized in Fig. 8.

As in the presence of helium, also the heat treatment in oxygen resulted in a shortening of the distance and a decrease in the Debye-Waller factor of the $\mathrm{Fe}-\mathrm{Fe}_{1}$ shell (see for comparison Table 4, Fe/ZSM5-He $30^{\circ} \mathrm{C} / \mathrm{LN}$ ). No differences were detected, on the other hand, in the coordination numbers of the $\mathrm{Fe}-\mathrm{Fe}$ shells, excluding $\mathrm{Fe}-\mathrm{Fe}$ agglomeration phenomena during the treatment.

\section{Discussion}

Several studies performed on Fe/ZSM5, obtained by CVD or solid-state ion exchange of $\mathrm{FeCl}_{3}$, have elucidated the evolution of iron along the different steps of the synthesis $[7,10,11,21,25,28,46]$, i.e., loading of iron, washing, and calcination. Upon sublimation of $\mathrm{FeCl}_{3}$, iron is exchanged for the $\mathrm{H}^{+}$Brønsted protons of the zeolite in the form of isolated $\mathrm{FeCl}_{2}{ }^{+}$species $[25,28,46]$. During the washing step, these species aggregate to form Fe-binuclear complexes, still bound to the framework aluminum $[25,28]$. The structure of the Fe-binuclear species in washed Fe/ZSM5, determined by EXAFS, resembles that of the closest Fe-binuclear building unit in $\alpha$-goethite [30,31], consisting of octahedrally coordinated $\mathrm{Fe}^{\mathrm{III}}$ oxo-hydroxo ions. A possible structure for the Fe-binuclear complexes, based on the similarity with the building blocks in $\alpha$-goethite [30,31], was proposed in our previous study [25] and is depicted in Fig. 9a. In this model hydroxo-bridged $\mathrm{Fe}$ atoms are bound to the framework via two oxo-ions, and balance the lattice extra charge of two aluminum atoms. The $\mathrm{Fe}-\mathrm{O}$ coordination, coherently with EXAFS and HR-XANES results, showing that iron possesses an octahedral coordination, is further completed by adsorbed water and by a terminal hydroxyl group. A similar model was presented by Marturano et al. [28], proposing a single oxo-bridge to the zeolite lattice.

The influence of calcination on the further evolution of the binuclear iron complexes was investigated in our previous work [25]. We have found that, if the calcination procedure is carefully controlled (mild calcination procedure), agglomeration of the binuclear Fe-complexes towards inactive oxidic clusters can be significantly suppressed, although not completely. This finding, based on HR-TEM, EELS, Mössbauer, FTIR, and EXAFS spectroscopy is confirmed by the results of the EXAFS analysis, presented in this work. Irrespective, to the different pretreatments applied (heating in $\mathrm{He}$ or $\mathrm{O}_{2}$ ), two $\mathrm{Fe}-\mathrm{Fe}$ shells could always be fitted, with a coordination number respectively of 1.2 and 0.4 (Tables 3-6). The closest $\mathrm{Fe}-\mathrm{Fe}$ shell $\left(\mathrm{Fe}-\mathrm{Fe}_{1}\right)$ is ascribed to the presence of binuclear $\mathrm{Fe}$ complexes [25,28]. The fact that the coordination number $(N)$ of this shell is higher than 1.0, and that also a second $\mathrm{Fe}-\mathrm{Fe}$ shell $\left(\mathrm{Fe}-\mathrm{Fe}_{2}\right)$ could be fitted at a higher distance ( $R=3.40 \AA, N=0.4)$, suggests that a fraction of iron possesses a higher degree of agglomeration than the binuclear complexes [25]. Nevertheless, from the EXAFS coordination numbers of the $\mathrm{Fe}-$ Fe shells, binuclear clusters in mildly calcined Fe/ZSM5 are estimated to account for at least $70 \%$ of the total iron. It should be noted that quantification by Mössbauer 
a)

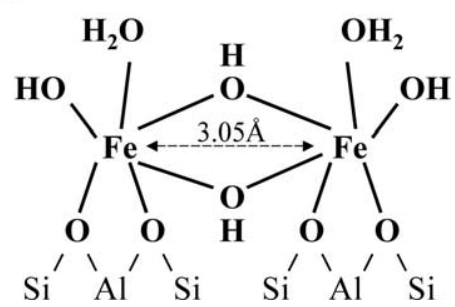

b)

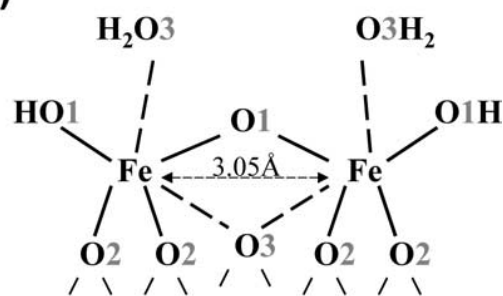

c) $\mathrm{Si}^{\prime} \mathrm{Al}^{\prime} \mathrm{Si}^{\prime} \mathrm{Si}^{\prime} \mathrm{Al}^{\prime} \mathrm{Si}$<smiles>C1CO[In]C1</smiles>

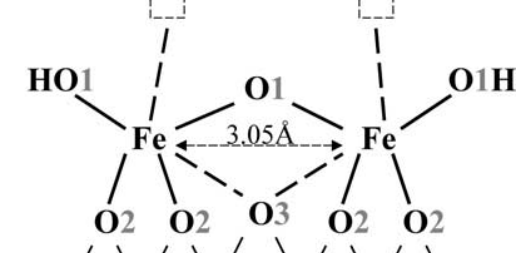<smiles>[SiH3][AlH2][SiH2][SiH2][SiH2][SiH2][SiH2][SiH3]</smiles>

d)

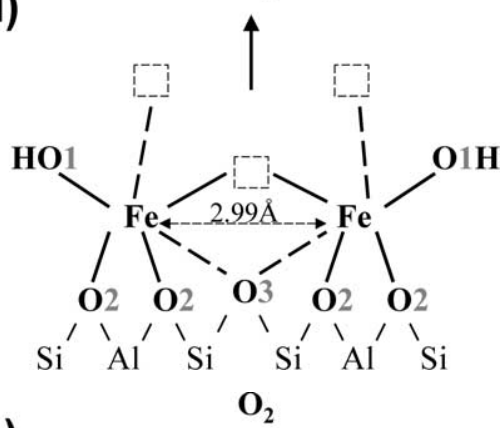

e)

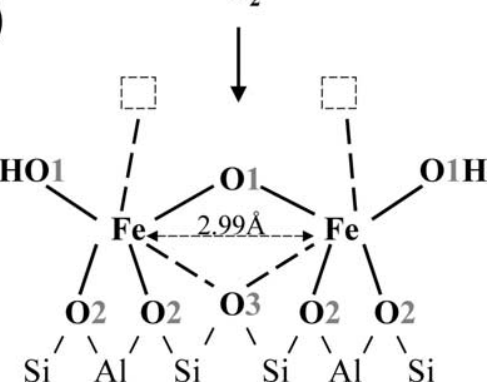

Fig. 9. Proposed structure for the binuclear Fe complexes in Fe/ZSM5 obtained by CVD of $\mathrm{FeCl}_{3}$ upon: (a) washing; (b) mild calcination and treatment in $\mathrm{He}$ at $30^{\circ} \mathrm{C}$; (c) mild calcination and moderate heating (up to $\sim 150^{\circ} \mathrm{C}$ ) in $\mathrm{He}$ or $\mathrm{O}_{2} / \mathrm{He}(50: 50)$ : desorption of water; (d) mild calcination and heating in $\mathrm{He}$ to $350^{\circ} \mathrm{C}$ : auto-reduction of iron, ascribed to the removal of the $\mathrm{Fe}-\mathrm{O}-\mathrm{Fe}$ bridging oxygen atom; (e) mild calcination and heating to $350^{\circ} \mathrm{C}$ in a $\mathrm{O}_{2} / \mathrm{He}$ (50:50) gas mixture: the presence of oxygen in the gas phase inhibits the removal of the $\mathrm{Fe}-\mathrm{O}-\mathrm{Fe}$ bridging oxygen atom. spectroscopy has shown that this number could be overestimated [25].

\subsection{Binuclear iron complexes in mildly calcined Fe/ZSM5, pretreated in $\mathrm{He}$ at $30^{\circ} \mathrm{C}$}

While calcination is generally applied as an activation procedure for $\mathrm{Fe} / \mathrm{ZSM} 5$ obtained by $\mathrm{CVD}$ of $\mathrm{FeCl}_{3}$ [10$12,25]$, its influence on the local $\mathrm{Fe}-\mathrm{O}$ coordination of the Fe-binuclear complexes, formed upon washing, has not been unraveled, yet. The features of the Fe K pre-edge of (mildly calcined) Fe/ZSM5 measured in $\mathrm{He}$ at $30^{\circ} \mathrm{C}$ (Fig. 1b) show that iron has a slightly distorted octahedral coordination and an oxidation state of III [35]. These results are confirmed by the position of the Fe K edge (Fig. 3a), which overlaps with that of the $\mathrm{Fe}^{\mathrm{III}}$ hematite reference, and by the results of the EXAFS analysis (Table 3), showing the presence of six oxygen neighbors in the Fe-coordination sphere. The EXAFS data could be fitted with a symmetric oxygen distribution in two (model 3:3) or three (model 2:2:2) oxygen shells. A plausible structure for the binuclear $\mathrm{Fe}$ complexes in mildly calcined Fe/ZSM5 after pretreatment in $\mathrm{He}$ at $30^{\circ} \mathrm{C}$, arising from the EXAFS and the HRXANES results, is depicted in Fig. 9b (oxygen atoms are labeled consistently with the 2:2:2 model in Table 3). This structure matches the model previously proposed in the literature $[7,10,11,17]$ for the catalytically active phase in calcined Fe/ZSM5, i.e., a binuclear Fe complex with the core structure $[\mathrm{HO}-\mathrm{Fe}-\mathrm{O}-\mathrm{Fe}-\mathrm{OH}]^{2+}$. This model is based on experimental evidence obtained by TPR, FTIR, and ESR studies [10-12,17] and appears as a plausible evolution of the binuclear complexes formed upon washing. The $\mathrm{Fe}-\mathrm{O}-\mathrm{Fe}$ bridging oxygen atom may result by the condensation at high temperature of two bridging hydroxyl groups with the desorption of a water molecule. A sufficient partial pressure of $\mathrm{O}_{2}$ in the gas phase during calcination should prevent migration and desorption of the bridging oxygen.

In the model presented in Fig. 9b, the two oxygen atoms located by the EXAFS analysis in the closest oxygen shell $\left(\mathrm{Fe}-\mathrm{O}_{1}\right)$ are assigned respectively to a bridging oxygen atom and a hydroxyl group. The $\mathrm{Fe}-\mathrm{O}_{1}$ distance $(1.86 \AA$ ) appears to be consistent with the average distance of a terminal $\mathrm{OH}$ group and a $\mathrm{Fe}-\mathrm{O}-\mathrm{Fe}$ bridging oxygen. Molecular modeling calculations performed on a binuclear $[\mathrm{OH}-\mathrm{Fe}-\mathrm{O}-$ $\mathrm{Fe}-\mathrm{OH}]^{2+}$ model-complex, bound to the zeolite framework via two oxo-ions [47], have found for the terminal $\mathrm{Fe}-\mathrm{OH}$ groups a distance of $1.88 \AA$ and for the bridging $\mathrm{Fe}-\mathrm{O}-\mathrm{Fe}$ oxygen atom a $\mathrm{Fe}-\mathrm{O}$ distance of $1.93 \AA$. Slightly shorter $\mathrm{Fe}-\mathrm{O}$ distances are nevertheless reported in the literature for $\mathrm{Fe}-\mathrm{O}-\mathrm{Fe}$ oxo-bridges (around $1.85 \AA$ ) [48]. EXAFS is therefore not able to discriminate between these two types of oxygen. Oxygen located in shell $\mathrm{Fe}-\mathrm{O}_{2}$ is ascribed to two bridging $(\mathrm{Fe}-\mathrm{O}-\mathrm{Al}) \mathrm{O}$-atoms, by which the iron atoms are stabilized to the zeolite lattice. Indeed, the $\mathrm{Fe}-\mathrm{O}_{2}$ distance of $1.97 \AA$ is consistent with the average distance found 
for oxygen in the $(\mathrm{Fe}-\mathrm{O}-\mathrm{Al})$ coordination of the mononuclear $\mathrm{FeCl}_{2}^{+}$complexes formed upon CVD of $\mathrm{FeCl}_{3}$ [25,28]. In our previous work [25] we found a distance of $1.99 \AA$. Marturano et al. [28], though optimizing their EXAFS fit by introducing two separate $\mathrm{Fe}-\mathrm{O}$ shells, found for the same $\mathrm{Fe}-\mathrm{O}-\mathrm{Al}$ coordination an average distance of $1.96 \AA$. Molecular modeling calculations, mentioned above, found for the $\mathrm{Fe}-\mathrm{O}-\mathrm{Al}$ bridges an average $\mathrm{Fe}-\mathrm{O}$ distance of $1.95 \AA$, thus consistent with the $\mathrm{Fe}-\mathrm{O}_{2}$ shell assignment. The most distant oxygen, located in shell $\mathrm{Fe}-\mathrm{O}_{3}$, is assigned to weakly bound oxygen as in adsorbed water. As discussed further, since upon heating to $350^{\circ} \mathrm{C}$ the C.N. of shell $\mathrm{Fe}-\mathrm{O}_{3}$ appeared to be reduced from 2 to only 1 , oxygen atoms were not completely assigned to adsorbed water molecules. As depicted in Fig. 9b the second oxygen neighbor in $\mathrm{Fe}-\mathrm{O}_{3}$ was tentatively assigned to a $\mathrm{Si}-\mathrm{O}-\mathrm{Si}$ bridging oxygen of the zeolite framework.

\subsection{Heat treatment in He (auto-reduction)}

During heating in He different changes are revealed with increasing temperature in the $\mathrm{Fe}-\mathrm{O}$ coordination of the Fe-binuclear complexes. Heating to $120^{\circ} \mathrm{C}$ results in an increase of the integrated intensity of the $\mathrm{Fe} \mathrm{K}$ pre-edge (Figs. 1a and b). This is the result of a decrease in the centrosymmetry of the coordination of the Fe atoms [35], caused by a lowering in the number of oxygen neighbors. The EXAFS fit reveals indeed a slight decrease, from 2.1 to 1.4 , in the coordination number of the most distant $\mathrm{Fe}-\mathrm{O}$ shell $\left(\mathrm{Fe}-\mathrm{O}_{3}\right.$, Table 4). Shell $\mathrm{Fe}-\mathrm{O}_{3}$ therefore contains weakly bound oxygen, coherently with its elongated $\mathrm{Fe}-\mathrm{O}$ bond. Since the decrease in the $\mathrm{Fe}-\mathrm{O}_{3}$ coordination number is not accompanied by a reduction in the oxidation state of iron, as revealed by the position of both the pre-edge centroid (Fig. 1b) and the Fe K edge (Fig. 3a), removal of oxygen up to $120^{\circ} \mathrm{C}$ is ascribed exclusively to desorption of water, as depicted in Fig. 9c. No further changes are revealed in the results of the EXAFS fit. In particular, as already mentioned, no changes were visible in the fit of the $\mathrm{Fe}-\mathrm{Fe}$ coordination, excluding further agglomeration of iron during heating.

An additional increase of the temperature under flowing helium caused clear changes in the features of the Fe K pre-edge (Figs. 1a and b), showing a clear reduction in the average oxidation state of iron. Indeed, the centroid position and the integrated intensity of $\mathrm{Fe} / \mathrm{ZSM} 5$, already at $260^{\circ} \mathrm{C}$, correspond to those of a reference $50: 50{ }^{(6)} \mathrm{Fe}^{\mathrm{III}} /{ }^{(4)} \mathrm{Fe}^{\mathrm{II}}$ physical mixture [35]. A slight additional reduction was revealed at $350{ }^{\circ} \mathrm{C}$. The reduction is confirmed by the clear shift $(\sim 4 \mathrm{eV})$ to lower energy of the Fe K edge (Fig. 6a).

These results show that, at high temperature in He, oxygen must be activated and removed from the $\mathrm{Fe}-\mathrm{O}$ coordination of the binuclear complexes. Auto-reduction phenomena associated to desorption of oxygen at high temperature are known in the literature for $\mathrm{Fe} / \mathrm{ZSM} 5$ prepared by CVD or solid-state ion exchange of $\mathrm{FeCl}_{3} \cdot \mathrm{O}_{2}$-TPD experiments, performed by Voskoboinikov et al. [49] on
Fe/ZSM5 obtained by CVD on acidic supports with different $\mathrm{Si} / \mathrm{Al}$ ratios, have shown that oxygen can be desorbed from Fe/ZSM5 by merely heating. Furthermore, the amount of oxygen released increases with decreasing $\mathrm{Si} / \mathrm{Al}$ ratios. Lobree et al. [21] have come to similar conclusions studying the auto-reducibility of iron in Fe/ZSM5 obtained by solidstate ion exchange. They found that, at a fixed $\mathrm{Si} / \mathrm{Al}$ ratio (S.A.R. was 25 in their experiments), the auto-reducibility of iron can be strongly enhanced by increasing the iron loading, i.e., by reducing the average distance of the iron atoms in the zeolite channels. Kucherov and Shelef [46] reached an identical conclusion using EPR spectroscopy. Activation of oxygen should therefore be facilitated by the close interaction of $\mathrm{Fe}$ atoms as in the case of Fe-binuclear clusters. The best suited candidate for the reactivity in He appears to be the bridging oxygen atom between the two Fe atoms. This hypothesis is supported by results obtained through ${ }^{18} \mathrm{O}_{2}$ isotopic exchange studies [26]. The experiments, performed on Fe/ZSM5 obtained by CVD, have shown a R1 isotopic exchange mechanism, prevailing at temperatures up to $450{ }^{\circ} \mathrm{C}$, i.e., molecular oxygen from the gas phase exchanges only one ${ }^{18} \mathrm{O}$ atom against a ${ }^{16} \mathrm{O}$ atom from the solid. On Fe/ZSM5 obtained via impregnation, on the contrary, where the presence of binuclear complexes have been demonstrated to be negligible [26], a R2 mechanism prevails, in which ${ }^{18} \mathrm{O}_{2}$ is exchanged in one step against two ${ }^{16} \mathrm{O}$ atoms.

The analysis of the Fe/ZSM5 EXAFS data recorded in $\mathrm{He}$ at $350^{\circ} \mathrm{C}\left(\mathrm{Fe} / \mathrm{ZSM} 5-\mathrm{He} 350^{\circ} \mathrm{C}(1 \mathrm{st})\right)$ shows that the reduction in the oxidation state of $\mathrm{Fe}$ is accompanied by a removal of oxygen from the closest $\mathrm{Fe}-\mathrm{O}$ shell $\left(\mathrm{Fe}-\mathrm{O}_{1}\right.$, Table 5). The coordination number of shell $\mathrm{Fe}-\mathrm{O}_{1}$ is reduced from 2.0 to 1.2 , coherently with the removal of bridging $\mathrm{Fe}-$ $\mathrm{O}-\mathrm{Fe}$ oxygen. Shell $\mathrm{Fe}-\mathrm{O}_{2}$ remains unmodified, confirming the correctness of its assignment to $\mathrm{Fe}-\mathrm{O}-\mathrm{Al}$ bridges, while only a slight further decrease is revealed in shell $\mathrm{Fe}-\mathrm{O}_{3}$. This is probably the result of further desorption of water with time on stream. A slight contraction is also visible in the $\mathrm{Fe}-\mathrm{Fe}$ interatomic distance. By comparison with the $\mathrm{Fe}-\mathrm{Fe}$ distance measured after cooling to $77 \mathrm{~K}$ (Fe/ZSM5-He $350^{\circ} \mathrm{C} / \mathrm{LN}$, Table 4), the contraction cannot be ascribed to temperature effects and is probably the result of a rearrangement of the complexes upon heating. From the body of the HR-XANES and EXAFS results, the most plausible structure for the binuclear complexes in $\mathrm{He}$ at $350{ }^{\circ} \mathrm{C}$ is depicted in Fig. 9d. At this stage of the treatment two vacancies have been created in the coordination of iron by the desorption of respectively a weakly bound water molecule $\left(\mathrm{Fe}-\mathrm{O}_{3}\right)$ and bridging oxygen $\left(\mathrm{Fe}-\mathrm{O}_{1}\right)$. A discussion still open in the literature concerns the possibility of liberating gaseous $\mathrm{O}_{2}$ by spatially separated oxo-complexes, such as [HO-Fe-O-Fe-OH $]^{2+}$, having only one bridging oxygen atom. Voskoboinikov et al. [26] have suggested that such complexes might communicate with each other via the $\mathrm{O}_{2}{ }^{-}$ions of the zeolite. Neighboring $\mathrm{Fe}-$ $\mathrm{O}-\mathrm{Fe}$ complexes, separated by a limited number of $\mathrm{O}_{2}{ }^{-}$ 
ions of the support, could disproportionate into one $\mathrm{Fe}-$ $\mathrm{O}-\mathrm{O}-\mathrm{Fe}$ and one $\mathrm{Fe}-\square-\mathrm{Fe}$ complex, where $\square$ stands for a vacancy. Oxygen could be subsequently easily desorbed by the (generated) highly unstable peroxo-complex. Such a mechanism would require the existence of Fe-binuclear complexes bound to pairs of Al-centered tetrahedra in close proximity with each other. This condition could indeed be fulfilled by a significant fraction of the iron complexes in over-exchanged $\mathrm{Fe} / \mathrm{ZSM} 5(\mathrm{Fe} / \mathrm{Al}=1)$ with a high $\mathrm{Al} / \mathrm{Si}$ ratio.

Although a significant fraction of the Fe-binuclear complexes can undergo autoreduction in $\mathrm{He}$ at relatively low temperature $\left(\sim 250^{\circ} \mathrm{C}\right)$, they appear to be highly unstable. This was revealed by the differences in the XAFS spectra recorded with time on stream at $350^{\circ} \mathrm{C}$ and at $77 \mathrm{~K}$ after 120 min stabilization in $\mathrm{He}$ at $350^{\circ} \mathrm{C}$. As seen in Fig. 6a, the $\mathrm{Fe}$ $\mathrm{K}$ edge appeared to be shifted stepwise to higher energy with exposure time, thus reoxidation of iron took place during the measurements. The reoxidation was accompanied by a reincrease in the coordination number of shell $\mathrm{Fe}-\mathrm{O}_{1}$ (Table 5). The remaining shells, on the contrary, remained virtually unchanged. This result confirms the previous observation that changes in the oxidation state of iron are related to only one oxygen atom in the closest $\mathrm{Fe}-\mathrm{O}$ shell $\left(\mathrm{Fe}-\mathrm{O}_{1}\right)$, most probably the $\mathrm{Fe}-\mathrm{O}-\mathrm{Fe}$ bridging atom. The reason for the reoxidation with time on stream is still unclear. While He with a very high purity was used (certified purity 5.0), additional oxygen traps were not added to the He line. It can therefore not be excluded that traces of oxygen from the gas phase might have partially reoxidized the Fe complexes. Nevertheless, reoxidation could also have been caused by oxygen released at high temperatures from the zeolite, supporting the idea of Voskoboinikov et al. [26] of an easy oxygen exchangeability between the zeolite and the Fe-binuclear complexes.

\subsection{Heat treatment in the presence of $\mathrm{O}_{2}$}

Up to a moderate temperature, the addition of oxygen to the helium flow does not cause significant changes to the coordination of iron. Heating $\mathrm{Fe} / \mathrm{ZSM} 5$ to $160^{\circ} \mathrm{C}$ in oxygen results in an increase of the $\mathrm{Fe} \mathrm{K}$ pre-edge intensity (Figs. 2a and b) similar to that measured in $\mathrm{He}$ at $130^{\circ} \mathrm{C}$ (Fig. 1a and b). As in the case of He, this is ascribed to desorption of water, coordinated to the binuclear complexes upon exposure of the Fe/ZSM5 sample to air. As expected, desorption of water is not influenced by the presence of oxygen (Fig. 9c).

On the contrary, changes occurring to the binuclear complexes at higher temperatures (from 130 to $350{ }^{\circ} \mathrm{C}$ ) appeared to be strongly influenced by the presence of oxygen in the gas phase. As seen from Fig. 2b, which collects the pre-edge features of Fe/ZSM5 heated in oxygen, the oxidation state of iron remained unchanged $\left(\mathrm{Fe}^{\mathrm{III}}\right)$ up to $350^{\circ} \mathrm{C}$. This result is confirmed by the position of the $\mathrm{Fe}$ $\mathrm{K}$ edge, which overlaps with that of the hematite reference and of $\mathrm{Fe} / \mathrm{ZSM} 5$ measured at $30^{\circ} \mathrm{C}$ (Fig. 7a). These results show that the presence of oxygen in the gas phase $\left(P_{\mathrm{O}_{2}}=\right.$ 0.5 bar) suppresses the autoreduction capability revealed by the binuclear complexes at the same temperature in $\mathrm{He}$. The intensity of the $\mathrm{Fe} \mathrm{K}$ pre-edge in oxygen at $350^{\circ} \mathrm{C}$ is similar to that of the five-fold coordinated $\mathrm{Fe}^{\mathrm{III}}$ reference (Fig. 2b) [35]. Consistently, five oxygen neighbors have been identified by the EXAFS analysis (Table 6). As at $350^{\circ} \mathrm{C}$ in helium, only one oxygen is located in the $\mathrm{Fe}-\mathrm{O}_{3}$ shell, in agreement with the removal of one water molecule during heating. The distance of the remaining oxygen in the $\mathrm{Fe}-\mathrm{O}_{3}$ shell appears to be slightly shortened, pointing to a stronger bond of the $\mathrm{Fe}$ to the zeolite $\mathrm{Si}-\mathrm{O}-\mathrm{Si}$ oxygen. Shell $\mathrm{Fe}-\mathrm{O}_{2}$, assigned to two oxygen atoms of $\mathrm{Fe}-\mathrm{O}-\mathrm{Al}$ bridges, remained unchanged, consistently with the assignment. As can be seen also qualitatively, by comparing the $k^{1}$ Fourier transforms depicted in Fig. 7c, the difference in the $\mathrm{Fe}-\mathrm{O}$ coordination of the binuclear complexes at $350^{\circ} \mathrm{C}$ in the presence or absence of oxygen are localized at low $R$. The EXAFS analysis revealed, indeed, that different from the measurement in $\mathrm{He}$ at $350{ }^{\circ} \mathrm{C}$, in the presence of oxygen the coordination number of the $\mathrm{Fe}-\mathrm{O}_{1}$ shell remains 2 , as it was in $\mathrm{Fe} / \mathrm{ZSM} 5$ measured in $\mathrm{He}$ at $30^{\circ} \mathrm{C}$. This result confirms that the $\mathrm{Fe}^{\mathrm{II}} \leftrightarrow \mathrm{Fe}^{\mathrm{III}}$ red-ox reversibility in the binuclear complexes is related to one oxygen atom located in shell $\mathrm{Fe}-$ $\mathrm{O}_{1}(R=1.86 \AA)$. According to the model proposed by Chen et al. [10-12] this atom is assigned to a $\mathrm{Fe}-\mathrm{O}-\mathrm{Fe}$ bridging oxygen (Fig. 9e). In the presence of a significant partial pressure of oxygen in the gas phase its removal (desorption) from the Fe complexes appears to be inhibited.

\section{Conclusions}

The analysis of the EXAFS and HR-XANES data obtained from mildly calcined Fe/ZSM5 shows that the majority of iron is present as Fe oxo-hydroxo binuclear complexes. The closest $\mathrm{Fe}-\mathrm{O}$ coordination of the Fe-binuclear complexes can be described with a $[\mathrm{HO}-\mathrm{Fe}-\mathrm{O}-\mathrm{Fe}-\mathrm{OH}]^{2+}$ core.

Heat treatments to $350{ }^{\circ} \mathrm{C}$ in $\mathrm{He}$ and in a $50: 50 \mathrm{O}_{2} / \mathrm{He}$ mixture do not cause further agglomeration of iron. Heating to a moderate temperature (up to $\sim 150{ }^{\circ} \mathrm{C}$ ) results in the desorption of water from the $\mathrm{Fe}$ coordination sphere. As expected, desorption of water is unaffected by the composition of the gas phase $\left(\mathrm{He}\right.$ or a $50: 50 \quad \mathrm{O}_{2} / \mathrm{He}$ mixture).

On the contrary, the composition of the gas phase strongly influences the changes occurring to the binuclear complexes in the $150-350^{\circ} \mathrm{C}$ temperature range. By heating in $\mathrm{He}$ a significant fraction of iron is reduced (auto-reduction). This is accompanied by the removal of approximately one oxygen atom from the closest $\mathrm{Fe}-\mathrm{O}$ shell, attributed to the $\mathrm{Fe}-\mathrm{O}-\mathrm{Fe}$ bridging oxygen atom. The reduced binuclear complexes appear to be highly unstable and undergo reoxidation with time on stream. 
The presence of oxygen in the gas phase $\left(P_{\mathrm{O}_{2}}=0.5 \mathrm{bar}\right)$ suppresses the auto-reduction capability of the binuclear complexes by inhibiting the removal of the $\mathrm{Fe}-\mathrm{O}-\mathrm{Fe}$ bridging oxygen.

\section{Acknowledgments}

N. Haack, M. Hermann (Station X1.1 at Hasylab, Hamburg), G. Vankó, C. Henriquet (Station ID16 at ESRF, Grenoble), and D. Keller (Department of Inorganic Chemistry and Catalysis, Utrecht University) are kindly thanked for their assistance during the X-ray absorption measurements.

The European Union program for Large Scale Facilities (Contract ERBFMGECT950059) and NWO (Contract 326710) are acknowledged for financial support.

\section{References}

[1] G.I. Panov, A. Kharitonov, V. Sobolev, Appl. Catal. 98 (1993) 1.

[2] G.I. Panov, V. Sobolev, K.A. Dubkov, V.N. Parmon, N.S. Ovanesyan, A.E. Shilov, A.A. Shteinmann, React. Kinet. Catal. Lett. 61 (1997) 251.

[3] G.I. Panov, A.K. Uriarte, M.A. Rodkin, V.I. Sobolev, Catal. Today 41 (1998) 365.

[4] G.I. Panov, Cattech. 4 (2000) 18.

[5] A. Ribera, I.W.C.E. Arends, S. de Vries, J. Pérez-Ramírez, R.A. Sheldon, J. Catal. 195 (2000) 287.

[6] F. Kapteijn, G. Marbán, J. Rodríguez-Mirasol, J.A. Moulijn, J. Catal. 167 (1997) 256.

[7] E.M. El-Malki, R.A. van Santen, W.M.H. Sachtler, J. Catal. 196 (2000) 212.

[8] J. Pérez-Ramírez, F. Kapteijn, G. Mul, J.A. Moulijn, Chem. Commun. 693 (2001).

[9] J. Pérez-Ramírez, F. Kapteijn, G. Mul, J.A. Moulijn, Appl. Catal. B 35 (2001) 227.

[10] H.Y. Chen, W.M.H. Sachtler, Catal. Today 42 (1998) 73.

[11] H.-Y. Chen, T. Voskoboinikov, W.M.H. Sachtler, J. Catal. 180 (1998) 171.

[12] H.-Y. Chen, T. Voskoboinikov, W.M.H. Sachtler, Catal. Today 54 (1999) 483.

[13] J. Pérez-Ramírez, G. Mul, F. Kapteijn, J.A. Moulijn, A.R. Overweg, A. Doménech, A. Ribera, I.W.C.E. Arends, J. Catal. 207 (2002) 113.

[14] N.S. Ovanesyan, A.A. Shteinman, V.I. Sobolev, K.A. Dubkov, G.I. Panov, Kinet. Katal. 39 (1998) 863.

[15] M.A. Rodkin, V.I. Sobolev, K.A. Dubkov, N.H. Watkins, G.I. Panov, Stud. Surf. Sci. Catal. 130 (2000) 875.

[16] K.A. Dubkov, N.S. Ovanesyan, A.A. Shteinman, E.V. Starokon, G.I. Panov, J. Catal. 207 (2002) 341.

[17] H.-Y. Chen, E.M. El-Malki, X. Wang, R.A. van Santen, W.M.H. Sachtler, J. Mol. Catal. A 162 (2000) 159.
[18] X. Feng, W.K. Hall, J. Catal. 166 (1997) 368.

[19] M. Kögel, V.H. Sandoval, W. Schwieger, A. Tissler, T. Turek, Catal. Lett. 51 (1998) 23.

[20] R. Joyner, M. Stockenhuber, J. Phys. Chem. B 103 (1999) 5963.

[21] L.J. Lobree, I.-C. Hwang, J.A. Reimer, A.T. Bell, J. Catal. 186 (1999) 242.

[22] B.R. Wood, J.A. Reimer, A.T. Bell, J. Catal. 209 (2002) 151.

[23] F. Heinrich, C. Schmidt, E. Löffler, W. Grünert, Catal. Commun. 2 (2001) 317.

[24] M. Kögel, R. Mönnig, W. Schwieger, A. Tissler, T. Turek, J. Catal. 182 (1999) 470 .

[25] A.A. Battiston, J.H. Bitter, F.M.F. de Groot, A.R. Overweg, O. Stephan, J.A. van Bokhoven, P.J. Kooyman, C. van der Spek, G. Vankó, D.C. Koningsberger, J. Catal. 213 (2003) 251.

[26] T.V. Voskoboinikov, H.-Y. Chen, W.M.H. Sachtler, J. Mol. Catal. A 155 (2000) 155.

[27] P. Marturano, L. Drozdová, A. Kogelbauer, R. Prins, J. Catal. 192 (2000) 236.

[28] P. Marturano, L. Drozdová, G.D. Pirngruber, A. Kogelbauer, R. Prins, Phys. Chem. Chem. Phys. 3 (2001) 5585.

[29] A.A. Battiston, J.H. Bitter, D.C. Koningsberger, Catal. Lett. 66 (2000) 75.

[30] J.R. Rustad, A.R. Felmy, B.P. Hay, Geochim. Cosmochim. Acta 90 (1996) 1553.

[31] S. Suzuki, T. Suzuki, M. Kimura, Y. Takagi, K. Shinoda, K. Tohji, Y. Waseda, App. Surf. Science 109 (2001) 169-170.

[32] G. Dräger, R. Frahm, G. Materlik, O. Brummer, Phys. Stat. Sol. B 146 (1988) 287.

[33] D. Heumann, G. Dräger, S. Bocharov, J. Physique IV 7C2 (1997) 481.

[34] T.E. Westre, P. Kennepohl, J. de Witt, B. Hedman, K.O. Hogson, E.I. Solomon, J. Am. Chem. Soc. 119 (1997) 6297.

[35] M. Wilke, F. Farges, P.-E. Petit, G.E. Brown Jr., F. Martin, Am. Miner. 86 (2001) 714.

[36] F. Sette, G. Ruocco, M. Krisch, U. Bergmann, C. Masciovecchio, V. Mazzacurati, G. Signorelli, R. Verbeni, Phys. Rev. Lett. 75 (1995) 850.

[37] M. Vaarkamp, B.L. Mojet, F.S. Modica, J.T. Miller, D.C. Koningsberger, J. Phys. Chem. 99 (1995) 16067.

[38] S.L.M. Schroeder, Adv. Spectrosc. 26 (1998) 1.

[39] M. Vaarkamp, J.C. Linders, D.C. Koningsberger, Physica B 209 (1995).

[40] M. Vaarkamp, I. Dring, R.J. Oldman, E.A. Stern, D.C. Koningsberger, Phys. Rev. B 50 (1994) 7872.

[41] D.C. Koningsberger, B.L. Mojet, G.E. van Dorssen, D.E. Ramaker, Top. Catal. 10 (2000) 143.

[42] J.W. Cook, D.E. Sayers, J. Appl. Phys. 52 (1981) 5024.

[43] A.L. Ankudinov, J.J. Rehr, Phys. Rev. B 56 (1997) R1712.

[44] D.C. Koningsberger, Jpn. J. Appl. Phys. 32 (1993) 877.

[45] G.G. Li, F. Bridges, C.H. Booth, Phys. Rev. B 52 (1995) 6332.

[46] A.V. Kucherov, M. Shelef, J. Catal. 195 (2000) 112.

[47] A.A. Battiston, D. de Romph, F.M.F. de Groot, J.H. Bitter, D.C. Koningsberger, manuscript in preparation.

[48] H.F. Hsu, Y. Dong, L. Shu, V.G.J. Young, L.J. Que, J. Am. Chem. Soc. 121 (1999) 5230.

[49] T.V. Voskoboinikov, H.-Y. Chen, W.M.H. Sachtler, Appl. Catal., B 19 (1998) 279. 